\title{
The Mourning of Thetis: 'Allusion' and the Future in the Iliad
}

\author{
Adrian Kelly
}

The papers in this volume, and the conference at which they were first delivered, represent a necessary attempt to exploit (further) the common ground between the two major schools of Homeric scholarship at the end of the first decade in the 21st century - Oral Poetry theory ${ }^{1}$ and Neoanalysis. Of course, most scholars today do not belong exclusively to either camp, and such attempts are not new; the possibility of rapprochement was heralded long ago, notably, by the late Malcolm Willcock $:^{2}$

$[\mathrm{T}]$ here is nothing inherently inconsistent between neoanalysis and oral poetry theory; indeed the two attitudes could be quite easily assimilated.

This conference itself is testament to these sentiments, but before we leap straight into the swift and pleasingly warm currents of conciliation, let us remember that disagreement and criticism between the two positions still have a role to play. Indeed, even the strongest of differences can contribute to the ongoing program of synthesis, partially because essential similarities can make themselves felt. As Bill Allan's recent analysis of the famous - and famously contentious - expression $\Delta$ iòs $\delta^{\prime}$ 'ं

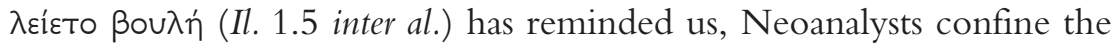
expression's semantic potential to an allusion to a specific story from a particular 'text' (in this case the depopulation of the earth heralded at

1 Actually a misnomer, the term is now standard; cf. Janko (1998). I prefer 'Oralism'.

2 Willcock 1997, 175; cf. also 189: "there can be a close similarity of approach between neoanalysis and oral poetry theory; the two schools can fruitfully cross-pollinate. In alliance with oral theory, neoanalytical preconceptions, by drawing attention to some sources of Homer's creativity, may be described as restoring the poet to the poetry". Though Kullmann 1984 is often described in the same terms, it hardly qualifies (Kelly 2006, 2 n. 4); cf. most recently Burgess 2006. A notable precursor to Willcock is Edwards 1990, and the balanced approach to the question he brings to his volume of the Cambridge Iliad commentary 1991. 
the start of the Cypria), ${ }^{3}$ whilst a new generation of Oralist scholars, describing the 'resonant' or 'referential' dynamic of the Homeric poems with the tradition as a whole, ${ }^{4}$ necessarily broaden this type of potential to encompass all the stories on every level to which this kind of expression could occur (the permanent facts of Zeus' reign, his plan to lighten the earth, the destruction of Troy, and the plot of the Iliad itself). Though there are fundamental differences in both their methods and assumptions, both schools concentrate on the semantic potential of factors external to the text itself.

Disagreement between them, however, has yet another vital purpose, for there remain a significant number of cases where - at least to someone working from an Oralist perspective - the rightness of the Neoanalysts' conclusions should not simply be assumed. If, for example, scholars like Jonathan Burgess are generally justified to take on these conclusions and then reform them along the lines adumbrated

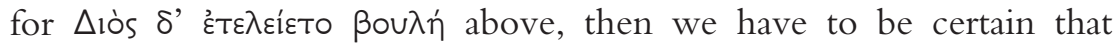
each conclusion warrants that treatment. ${ }^{5}$

In this spirit, the current article will examine the mourning of Thetis and the Nereids at the start of Iliad Book 18, an episode usually regarded as one of the oldest and most central planks of Neoanalysis. Against the current consensus, and perhaps the mood of many of the contributions in this volume, I will attempt to demonstrate that this episode does not support the Neoanalytical belief that Homer is appropriating material from an Achilleis, Aethiopis or Memnonis in this portion of the Iliad. The scene is neither as unique, poorly motivated or unusual as it has seemed or been deemed by Neoanalysts, nor is its material better situated in another story or text. I will further attempt to show that its primary function is not to allude to the death of Achilles beyond the end of the Iliad, and will also suggest a solution to the famous crux surrounding Thetis' prediction of her son's death 'immediately after' Hector's (18.95-96). Once we appreciate the fact that Thetis' mourning is a

3 Kullmann 1955; id. 1960, 228-229; contra Allan 2008.

4 Foley 1999; Graziosi and Haubold 2006; Kelly 2007, 1-14, esp. 5 n. 20.

5 As he said in an earlier work (Burgess 2001, 16), "if we can embrace neo-analysis as a 'working hypothesis' . . we still need to scrutinize its proposals one by one, rejecting and accepting them as seems appropriate." Burgess' recent work seems to have taken on Neoanalytical thinking more closely (cf., e.g., 2006 for his attempt at a working synthesis of Oralism and Neoanalysis), so that in this article he will be cited most often for supporting the Neoanalytical case on our target episode. 
meaningful and contextually motivated example of a sequence typical to Homeric compositional technique, we shall find that there is considerably less reason to invoke any other text / poem / story ${ }^{6}$ in order to interpret Homer's narrative. ${ }^{7}$

\section{Mourning Thetis and the Neoanalysts}

Let us start by reminding ourselves of the crucial portion of text. At the start of Iliad 18, Antilochus finds Achilles watching and wondering about the course of the fighting as it once more nears the ships. After a monologue in which Achilles ponders the fate of Patroclus and remembers his mother's prophecy that the 'best of the Myrmidons' would perish whilst he himself was still alive (18.5-15), the news is broken to him and he reacts like a mourner, throwing himself on the ground (16-27), and being joined by the chorus of slave women $(28-31)$ before being restrained by a fearful Antilochus (32-34). Hearing his cries, his mother Thetis under the sea expresses her grief for her child to her sister Nereids (35-37/51-64), after they gather to hear her $(37-50)$. Upon finishing this lamentation, the group then comes to the Greek camp (51-69) and Thetis and Achilles converse about his decision to return to the fighting, whereupon Thetis dismisses the Nereids $(138-145)$ and journeys on to Olympos to speak with Hephaestus about getting hold of a new suit of armour (146-148).

Though scholars were drawn to this scene well before the first Neoanalysts, ${ }^{8}$ its centrality to the method was established by the work of Pestalozzi and Kakridis, and it has been picked up and expatiated upon by every author belonging to this school. ${ }^{9}$ With variations de-

6 I use this clumsy periphrasis to include all the varieties of belief and terminology one can find in the writings of the Neoanalysts; cf. the discussion below, pp. $217-218$.

7 In that sense, this is a companion piece to Kelly 2006, with reply in Heitsch 2008.

8 Dihle 1970, 20 calls it "eine alte Beobachtung”; cf., e.g., Mülder 1910, 193, 197; also Kakridis 1949, 73-75.

9 Pestalozzi 1945, 26-27, 32; Kakridis 1949, 65-75; Kullmann 1960, 36-37, 331-332; Schoeck 1961, 43-44; Schadewaldt 1951/1965, 166; Kullmann 1981, 23; Kullmann 1984, 310; Danek 1998, 470-471; Edwards 1990, 311-312; Kullmann 1991, 440-441; Dowden 1996, 56; Kullmann 2005, 10; Burgess 2006, 161; Currie 2006, 25. The conclusion that this scene is de- 
pending on each scholar's individual predicates and aims, that case has drawn on two types of evidence, internal and external. The former, as its name suggests, concerns those several elements in this part of the narrative which have been judged not to fit the circumstances of the Iliad, and it is with those that we shall begin.

These elements are centred around the general theme of lamentation and its extraordinary prominence in this scene. The Neoanalysts have argued that, whilst the mourning for Patroclus by Achilles and the female slaves (18.16-31) has at least some point in the form of a dead hero, Thetis' grief is unusual and troubling, particularly when she has not yet heard what it is that is bothering her son. Moreover, though she is speaking firstly of and then to her son, who is not dead, her speeches and actions (indeed the whole scene) exhibit several features usually associated with actual lamentations for the dead: 'keen-

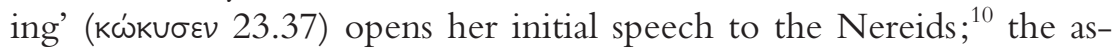
sembled Nereids beat their chests $(23.50-51)^{11}$ and she then 'leads off

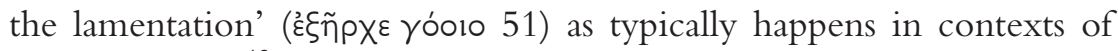
formal lament. ${ }^{12}$ Then they depart for the Greek camp weeping

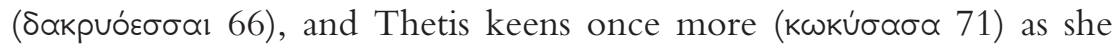

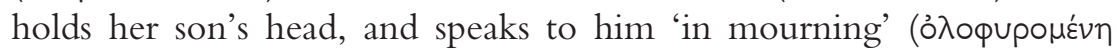
72). ${ }^{13}$ Given that Achilles is not dead, and that Patroclus hardly warrants such a prominent group of mourners, all this lamentation seems a little undermotivated. Furthermore, the chorus of Nereids itself appears a trifle otiose, both in their gathering around Thetis under the sea and in their somewhat purposeless presence in the Greek camp. Together, these features seem to suggest that the scene as a whole sits ill with the narrative of the Iliad.

rived from an earlier text / poem / story is now widely, in fact almost universally, held; cf., e.g., Burgess 2009, 83-84, esp. 83: "Neoanalysts often point to discrepancies as evidence for the reuse of traditional material, and this method works especially well in this scene" (my italics); Tsagalis 2004a, $10=2008$, 239240: "Thetis' lament for Achilles is an exceptional | event, especially (but not solely) because of its unsuitability to the Iliadic plot" (my italics); cf. also Tsagalis 2004, 136-139; contra those scholars below, n. 23.

10 Cf. Arnould 1990, 150-153.

11 Cf. Tsagalis 2004, 59-60.

12 Cf. also 18.316 (Achilles for Patroclus), 22.430 (Hecuba for Hector), 23.17 (Achilles for Patroclus), 24.723 (Andromache for Hector), 24.747 (Hecuba for Hector), 24.761 (Helen for Hector); Tsagalis 2004, 55-64.

13 Cf. Arnould 1990, 148-150. 
It was a natural next step to find a scene in early Greek epic where these elements do fit, and in this case it comes in the form of Achilles' actual death as narrated in the post-Homeric ${ }^{14}$ Aethiopis. To reconstruct this episode, Neoanalysts compare its narration at the end of the Odyssey (24.43-66), where the Nereids accompany Thetis 'from the sea' (55) as she journeys to Troy to mourn her son:

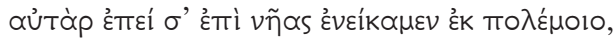

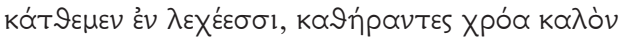

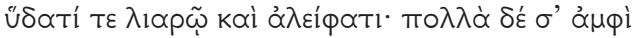

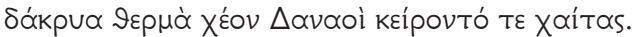

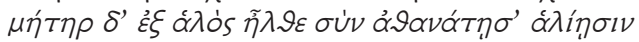

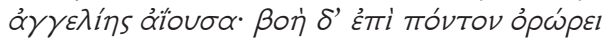

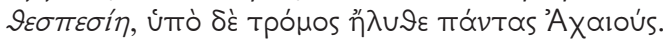

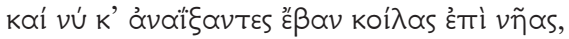

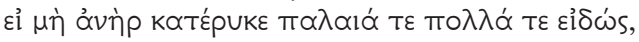

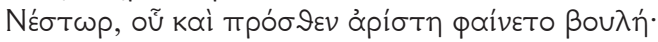
ŏ б

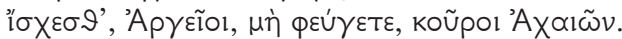

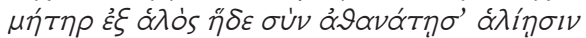

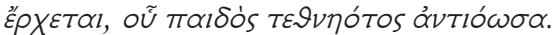
ஸิs है

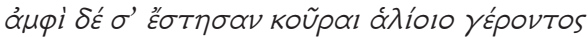

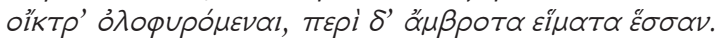

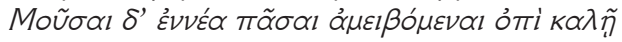

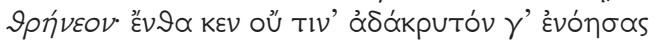

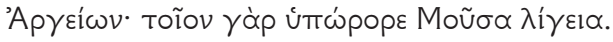

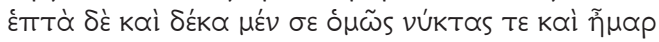

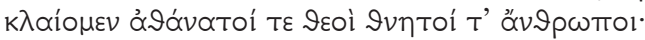

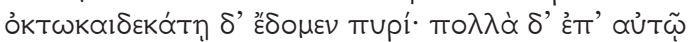

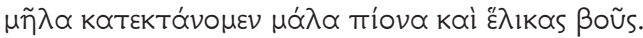

But when we carried you to the ships from the battle, we placed you on the bier, cleaning your fair skin with warm water and oil; and many warm tears about you did the Danaans pour forth and they cut their hair. And your mother from the sea came with her immortal sea-dwellers hearing the news; and a shout over the sea arose divine, and trembling came upon all the Achaeans. And now leaping up they would have gone for the hollow ships, if a man did not restrain them, knowing ancient and many things,

14 I make no judgement here about the absolute dating, priority or otherwise (visà-vis the Iliad) of any poem narrating these events, simply that the Aethiopis we know of is only attested in the post-Homeric period. 
Nestor, whose counsel even before seemed best;

he with kindly intention addressed and spoke among them;

'hold, Argives, do not flee, youths of the Achaeans.

His mother from the sea here with her immortal sea-dwellers

comes, to meet her dead child.

So he spoke, and the great-souled Achaeans checked their fear.

And around you they stood, the daughters of the old man of the sea,

grieving pitiably, and they set around you ambrosial clothes.

And the Muses, nine in all, replying with fair voice

sang the thrēnos; then you would have seen no man of the Argives

without tears; for such was the stirring of the clear voiced Muse.

And seventeen nights and days

did we weep, immortal gods and mortal men;

and on the eighteenth we gave you to the fire; and on it we killed

many finely fatted sheep and horned cattle.'

This concords very well ${ }^{15}$ with the summary of the Aethiopis contained in Proclus' Chrestomatheia (= Aethiopis arg. 20-24 Bernabé):

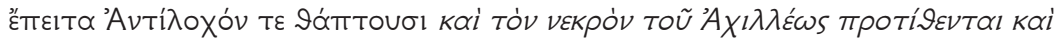

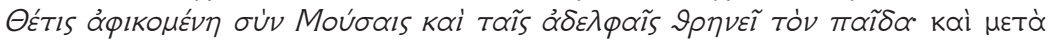

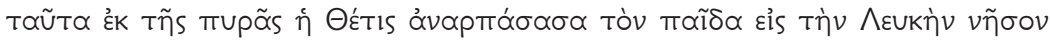

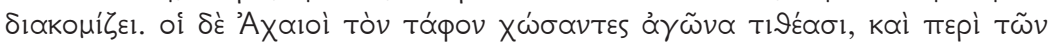

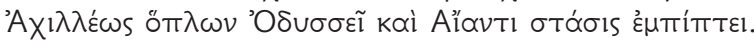

Then they bury Antilochus and they set out the corpse of Achilles and Thetis arriving with the Muses and her sisters mourns her child; and after this Thetis snatching up her child from the pyre conveys him to the White Island. And the Achaeans heaping up a burial mound hold games, and around Achilles' arms conflict falls upon Odysseus and Ajax.

When taken together, and particularly considering the antiquity of the Odyssey, this external evidence provides a neat explanation for the difficulties (vel sim.) one has found in the Iliad scene: Homer has there recast an episode from another text / poem / story in which the death of Achilles was narrated. On that supposition, the presence of the Nereids both under the sea and in the Greek camp is explained, as is the mourning of Thetis for her son, even before she speaks with him to find out

15 Dihle 1970, 21 argues that the discrepancy between these stories over the question of Achilles' translation to the White Island disproves a simple textual stemma between the Aethiopis and Homer. He further (22) notes the absence of the Muses from our target scene as an indication that the relationship between the texts is not quite so straightforward, and believes (somewhat like Fenik 1964, $31-33$ ) that the commonality of 'Totenklagen' in early Greek epic, which accounts for the type of similarities found between the scenes, removes the need or even warrant for us to think in terms of one model for the Iliad scene. 
the source of his current angst. These elements are now accounted for because Homer was drawing on another scene in another text / poem / story.

So runs a general summary of the assorted Neoanalytical treatments of this scene, though both the process, vocabulary and predicates of these authors show some variety, ${ }^{16}$ not only from scholar to scholar in the same generation (compare, for instance, the rigid Quellenforschungen of Pestalozzi and Schoeck with Kakridis' more sensitive criticism), but also when they are considered diachronically. A newer group of Neoanalysts, for instance, generally argues in terms not of 'errors' or 'alterations' of an older text / poem but as 'interactions' with or 'allusions' to that text / poem / story (Edwards, Currie, Burgess). This change in perspective has come about, partly, through confronting the obscurities in our knowledge about textual culture in the early Archaic period, and engaging more openly with the results of Oralist research into the tradition from which the poems have sprung. It can also be correlated with another shift in the Neoanalytical perspective: whilst these scholars once believed in variously named (and usually written) texts on or from which Homer was drawing in much the same way as a fully literate poet would, more recent authors show greater flexibility on this point, with e.g. Currie speaking (in a somewhat indistinct manner) of 'versions', 'songs' and 'poems, ${ }^{17}$ and Burgess of 'story traditions', whilst Willcock argued that Homer refers to his own previous performances, and not to an external entity such as another bard's text / poem / story, as the source of the signification. ${ }^{18}$

Yet, despite this progress, the older elements in the Neoanalytical heritage continue to make themselves felt, and not simply in the way that their target episodes in the Homeric texts are identified and deployed. Whilst some methodological predicates may have been altered for some recent authors following this line of research, ${ }^{19}$ the aim is still to establish the priority of the non-Homeric material, and it is

16 For a reliable introduction and narrative, cf. Willcock 1997 and now Burgess 2006.

17 Currie 2006; Allan 2008, 212 n. 37 correctly identifies the "marked slippage in his discussion between reference to other stories and actual quotation" and pertinently reminds us that " $[\mathrm{t}]$ he bard can refer to a story without referring to a text".

18 Willcock 1997, 188: "[t]here is no need to hypothesize an external source".

19 Not, however, Dowden 1996, 58 n. 40: "In my opinion, the most thoroughgoing and dependable of these texts is Kullmann's (viz. 1960)". 
sometimes very difficult to distinguish between the generations in their application of what seem to be very similar analytical criteria. ${ }^{20}$ Indeed, as already noted, the most recent treatment of the Thetis scene judges that "traditional Neoanalytical method seems to work very well here", ${ }^{21}$ and its discussion of the episode reads precisely like a classic exemplification of the school's unreconstructed methods. In fact, there exists at the moment no 'reformed' Neoanalytical treatment of the Thetis scene, ${ }^{22}$ and the older method seems to have driven the opposition from the field. ${ }^{23}$ This article aims to challenge that.

20 Cf., e.g., Currie 2006, 5, for whom allusion is possible through "untraditional, unique, forms of expression" and "the distinctive use by another poem of a traditional formula or motif or theme" (my italics). Herein lie the school's fundamental (and problematic) continuities, for the targeted element is still to be isolated from normal Homeric usage in order to reveal its 'interaction' with another text / poem (rather than the poet's error, as vetero-Neoanalysts had it). But this seems in practice not much more than a cosmetic change, as in the continued use of narrative inconsistency (one of Currie's (7) "indices of interaction") without any redefinition of the concept of (in) consistency itself. The best answer to such arguments remains the one which has been invoked against Neoanalysis since its inception: the inconsistency, properly understood and contextualised in the poet's traditional technique, is not an inconsistency at all. None of this means that allusion (vel sim.) is not possible, of course; it just means that the methods used to identify it remain vulnerable to the old criticisms.

21 Burgess 2009, 83; cf. also above, n. 9.

22 We await Currie (forthcoming). Edwards 1991 ad loc. might be considered such a treatment, though he too is concerned to think of the signals in the episode that Homer is using the externality of Achilles' actual funeral to inform his narrative. I hope to show that, if the poet is doing this, it is at best a secondary purpose.

23 For previous responses to the Neoanalytical case on this scene, cf. Hölscher 1955, 394 (within a larger critique of the method), who notes the parallel with Andromache's lament for Hector in Iliad 6 (see below, $\$ II (a), pp. 231-232 n. 29); Fenik (1964, 31-33) suggests that the Thetis scene is an "adaptation of a type scene, that is further represented both by her lament over her dead son in the Aithiopis and perhaps by that of Eos over Memnon as well" (32), and thus differentiates between the story of the funeral and the typical representations of the action; Foley (1991, 157-159) analyses this scene as a 'Suspicion of Death' traditional sequence, but compares only Andromache's lament for Hector in Book 22; also Dihle 1970, 20-22 (cf. above, n. 15). 


\section{Prospective Lamentation in Homer}

Let us therefore turn our attention to the posited traces of pre-Homeric material in the Iliad, the triggers, as it were, for Neoanalytical method. In order to identify that material, these scholars have scrutinised the text to find what is more or less appropriate, more or less meaningful etc., in the relationship between Homer's poem and his putative 'source' (text / poem / story). ${ }^{24}$ But none of them seem to have noticed that the type of action on which Thetis is engaged is a typical sequence in Homeric epic, being one of the most impressive and elaborate examples of what I term 'prospective lamentation' (hereinafter PL): (too) simply put, this is the prior generation of elements, actions and expressions associated with circumstances of formal lamentation - i.e. before that lamentation is actually required. ${ }^{25}$ In these circumstances, an individual and a group are combined in lamenting the imminent or even apparently accomplished death of a threatened figure, and there are eight examples in both Homeric poems:

Mourner

[1]

[2]

[3]

[4]
Agamemnon

Andromache

Thetis

Hecuba

\section{Mourned}

Menelaus

Hector

Achilles

Priam
Il. $4.148-182$
Il. $6.319-502$
Il. $18.35-145$
Il. $24.191-328$

24 I leave aside here a consideration of the difficulties surrounding the reconstruction of these sources, principally because there is an early narrative in the Odyssey to draw upon in the present case, unlike some others; cf. Kelly 2006, 13-24 for an example.

25 This is not an entirely new realisation; e.g., Stoevesandt $(2008,155)$ notes that "die vorzeitige Totenklage ist bei Homer ein wiederkehrendes Motiv", though she separates Andromache's lament for Hector and Thetis' for Achilles from "Situationen, in denen der Rezipient weiß, daß die beklagte Person nicht umkommen wird / umgekommen ist" (her italics). The fundamental study, Arnould (1990, 187-189) distinguishes between 'les déplorations funèbres' and 'anticipées', noting that the latter are more numerous, generally shorter and more structurally varied than the former, though she too (188) suggests (as I shall not) that "la mort de Patrocle est le substitut de la mort du Achille". The most recent and full exposition of lamentation conventions in the Iliad is Tsagalis (2004), but he does not analyse them as I have, does not discuss Hecuba's scene in Iliad 24 or Penelope's three scenes in the Odyssey (except the first, and then only in passing). Tsagalis $(2004 \mathrm{a})=(2008)$ focuses on the Thetis scene, though his examination takes "its unsuitability to the Iliadic plot" (Tsagalis (2004a) $10=(2008) 239-240)$ as axiomatic. 


$\begin{array}{llll}\text { [5] } & \text { Penelope } & \text { Odysseus }^{26} & \text { Od. 1.328-364 } \\ \text { [6] } & \text { Penelope } & \text { Telemachus } & \text { Od. 4.679-758 } \\ \text { [7] } & \text { Penelope } & \text { Odysseus } & \text { Od. 19.53-604 } \\ \text { [8] } & \text { Penelope } & \text { Odysseus } & \text { Od. 21.55-358 }\end{array}$

The typology informing these scenes comprises a two stage process where the individual mourner is a woman (i.e., all but the first example): ${ }^{27}$ a PL for an endangered figure in a (more) public place is followed by another (private) PL concerning that same figure, and the connection is made by having the lamenting character(s) in the first scene journey to the location of the second (for details, see below). Of the above eight examples, only [1] does not respond to this pattern, for reasons obviously linked with its particular narrative circumstances. ${ }^{28}$

This sequence is not typical in the sense of the arming scenes, in which a large amount of vocabulary and phraseology is repeated from one example to the next. It is more akin to the assembly scene, in which a cluster of details may or may not be repeated, but the progress of the framework is demonstrably consistent. Hence we should not expect uniformity between the examples of the sequence; rather we shall find a flexible scaffolding which the poet can adapt precisely to the requirements of his narrative.

Reflecting that quality, the following examination proceeds by stages; we begin (a) with the two examples which are closest in form to the Thetis scene [2] and [6], then (b) a scene in which both the gender and location of the sequence has been shifted [1]. Returning to patterns dominated by women (c), we turn our attention to three examples [5], [7] and [8] which are bound together not simply by repeated phraseology, but more importantly by the fact of being performed by the

26 This example is to be grouped very closely with [7] and [8] (cf. below, \ II (c), pp. 226-231), and not simply because there are considerable phraseological links between them, for instance in their concluding lines (Od.1.362-364 [5] = 19.602-604 [7] and 21.356-358 [8]). One might baulk at considering them examples of 'prospective' lamentation, when the object of the lament is generally considered dead, but there is considerable (if pessimistic) uncertainty in these individual scenes about Odysseus' fate (Od. 1.340-344, 354-355, $362-363$; 19.124-136, 141, 208-209, 257-260; 21.69-70) and Penelope in [6] also focuses on the same absent, but feared dead, figure (Od. 4.724-726).

27 On the unique properties of [4], where the narrative begins with a male mourner (Priam), moves to a female mourner (Hecabe), and then back to the first figure, cf. below, $\int$ II (d), pp. 231-235. For a schematic presentation of the examples, cf. below, Appendix, p. $255 \mathrm{f}$.

28 Cf. below, $\mathbb{S}$ II (b), pp. 224-226. 
same woman (Penelope) for the same, feared dead, figure (Odysseus). They are thus adaptations of the sequence for the particular circumstance where the lamented figure's whereabouts is unknown. Finally (d), having observed the fundamental continuities which link these examples despite their superficial variations, we examine the most exceptional example [4], which shows by its very denials and abnegations how ingrained was the sequence for the traditional poet. With this established, we can then turn (e) to Thetis' lamentation and the particular criticisms made of its placement, structure and motivation.

\section{II.a The Basic Pattern: [2] and [6]}

To begin our survey, Andromache's initial exchange with Hector [2] occurs above the Scaean gates and is replete with mourning elements: ${ }^{29}$

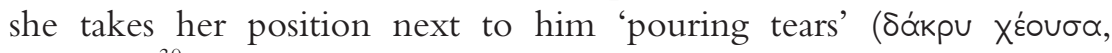
Il. 6.405), ${ }^{30}$ she bemoans her dependence on him by stressing the absence of support she will have to endure when he is dead (407-413, $429-439) ; 3^{31}$ finally, she leaves him to go home still in tears ( $\neg \alpha \lambda \varepsilon \rho \rho$ ov

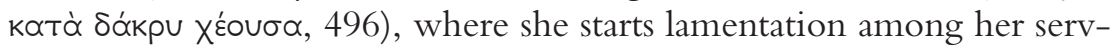
ants $(497-502)$ :

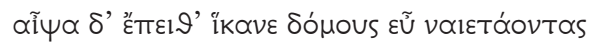

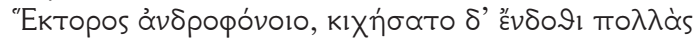

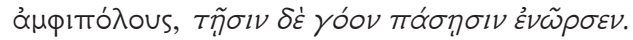

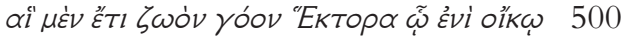

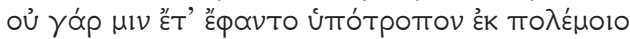

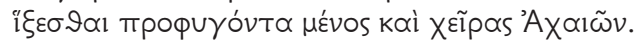

29 On this scene, cf. Lohmann 1988, 38-45; Arnould 1990, 81; Foley 1999, 187 99; Dué 2002, 68-76; Tsagalis 2004, 118-129; also Gagliardi 2006, $11-46$; Hölscher 1955 aptly comments on this scene's relationship with Thetis' lamentation: "das ist wie die 'Totenklage' der Andromache um den noch lebenden Hektor 6, 498, wohinter noch niemand eine 'wirkliche' Totenklage vermutet hat." Burgess $(2009,84)$ does note this parallel ("comparable to some degree"), but feels that Andromache's lament "is integrated into its context". Aside from the fact that he misses the other six parallel cases, I hope to show that his impression is entirely incorrect, at least as it regards the comparison with the Thetis scene. Even if it were not, a greater success in execution or level of care in one scene should not be held to prove the 'alien' provenance of another.

30 Cf. Arnould 1990, 130-131.

31 Cf. Tsagalis 2004, 30, 119. 
And straightaway then she came to the well-dwelt house of Hector manslaying, and she found within many servants, and she raised the lament in all of them.

They lamented Hector while he was still alive, in his own house; for they did not think he would come back from the war escaping the might and the hands of the Achaeans.

Though the poet does not detail the actual goos (as he does in [3] and [6], for instance), ${ }^{32}$ he summarises its content as the expectation that Hector would not return from battle again $(501-502)$. So a group PL for an endangered (absent) figure follows the individual PL addressed to the endangered (present) figure, with Andromache moving from one place to the other - public to private - in order to connect the two lamentations.

A very similar process is envisaged in Penelope's case in Odyssey Book 4 [6]. Upon being informed by Medon of Telemachus' dangerous trip and the suitors' plans to murder him (675-702), she suffers an extreme reaction which has obvious resonance with similar reactions to news of death (703-705):

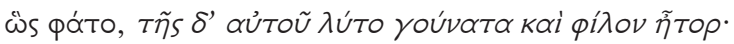

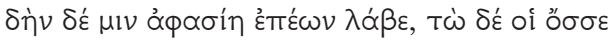

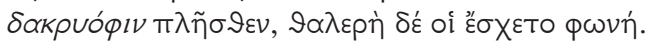

So he spoke, and there her knees and dear heart were loosened; for long speechlessness of words held her, and her two eyes were filled with tears, and her voice was checked from its vigour.

Her further questions of the herald elicit no more satisfactory information (706-714), and then the poet continues (715-726):

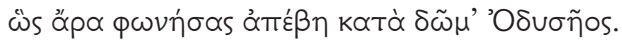

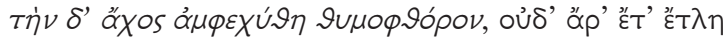

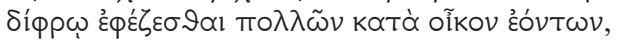

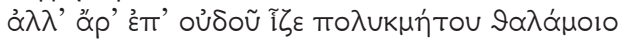

olk

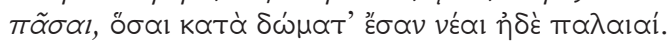

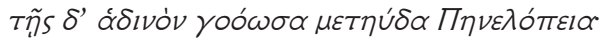

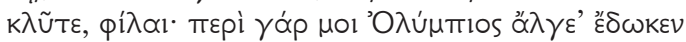

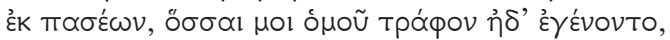

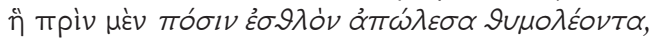

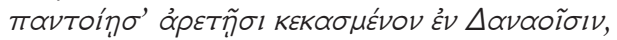

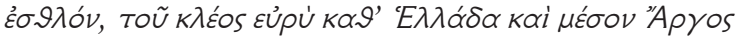

32 Cf. Il. $16.857=22.363,23.108,23.153,24.507,24.513$ and Tsagalis 2004, $171-174$. 
So speaking he went away through the house of Odysseus.

And pain that destroys the soul was poured round her, nor any more did she endure to sit on the chair though there were many in her house, but there on the threshold of the well made chamber she sat grieving pitiably; and about her the maids moaned all, all who were in the house, young and old. Among them spoke Penelope, groaning loudly;

'hear me, my friends; for to me the Olympian has given pains beyond all women who were raised and born together with me, I who beforehand lost a husband noble and with a lion's spirit, in all sorts of virtues outstanding among the Danaans, noble, whose fame spread broadly through Hellas and the midst of Argos.

... (exchange between Eurycleia and Penelope)

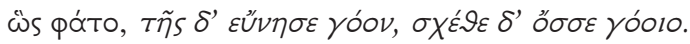

So she spoke, and she made her lament to rest, and held her eyes from lament.

Aside from the obvious (italicized) features of lamentation, note the praise of the husband so common in this context (also 687-695), ${ }^{33}$ though this time (because Medon has come to her) Penelope's initial reaction to the distressing news occurs within the household (right on the threshold between the two areas), where she is joined by her serving women, who then rouse a goos for the absent Telemachus which is only halted (758) by Eurycleia's suggestion that Penelope go and pray to Athene.

In these first two cases, the individual speech or exchange is variable according to the requirements of the narrative (journey of Hector / journey of Medon), whilst the group lamentation occurs within the interior of the home (Hector's house / Odysseus' house). Moreover, the female mourner is once more left dissatisfied and upset by this public exchange, ${ }^{34}$ with Penelope baulked from further knowledge about Telemachus' purpose and Andromache dismissed, however tenderly, from any role in the determinative process of war. We shall encounter this rebuff again, but it is important to flag it here because its purpose is

33 Tsagalis 2004, 28-29.

34 The exchange is 'public' in the second case in the sense that a male has entered Penelope's part of the house $(O d .4 .679-680)$ and conducts a conversation with her before leaving her alone (715) with her female attendants in a private setting. 
to point out the inappropriateness of lamentation or the feelings with which it is associated.

These two sequences are the closest analogues for Thetis' lamentation at the start of Iliad 18 [3], but there are many other examples to discuss before we can deal with that target case. The variety and flexibility of these cases is only possible, as we shall see, because the sequence is such a common part of the poet's technique.

\section{II.b The Pattern Compressed (and Regendered): [1]}

When Agamemnon sees his brother wounded (Il. 4.148-152), his reaction and following speech is crammed with themes and words of lamentation. ${ }^{35}$

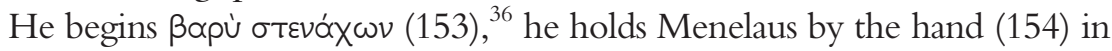
a manner reminiscent of the typical physical contact found in actual lamentations (e.g., Il. 23.136-137, 24.711-712, 723-724), ${ }^{37}$ and his com-

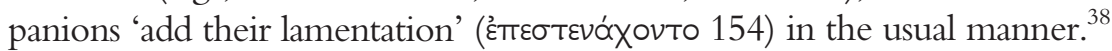
Agamemnon's following speech (155-182) details his own error in allowing the duel to take place and expresses his certainty about Troy's destruction (155-168), before negating their value (169-182):

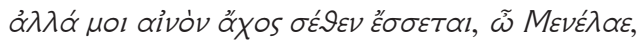

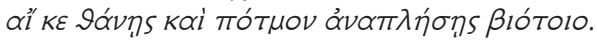

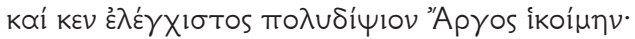

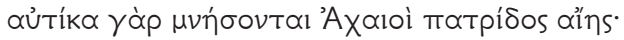

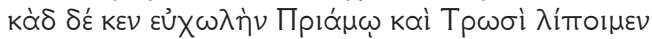

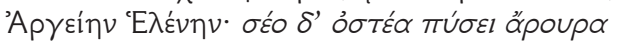

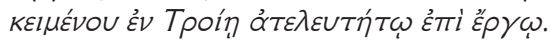

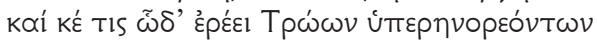

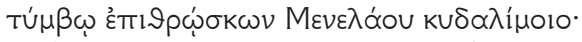

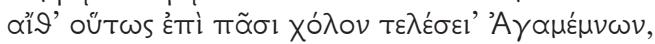

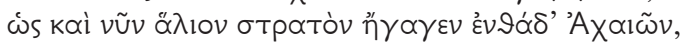

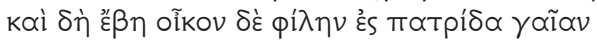

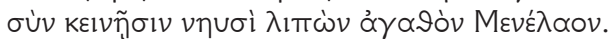

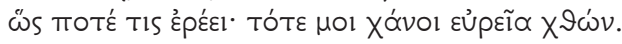

But dread pain there will be for me from you, o Menelaus, if you die and fill up the destiny of your life.

Even then most wretched would I come to thirsty Argos;

35 Arnould 1990, 55; Tsagalis 2004, 76-77, 90-91, 112-118.

36 Arnould 1990, 150-153.

37 Arnould 1990, 77-78; Tsagalis 2004, 58-60.

38 Arnould 1990, 173-175; Tsagalis 2004, 64-68. 
for immediately will the Achaeans think of their fatherland; and then we would leave as boast to Priam and the Trojans Argive Helen; but the field will cause your bones to rot as you lie in Troyland for a deed that was left undone. And someone of the overweening Trojans thus will speak leaping upon the tomb of lordly Menelaus; May Agamemnon thus complete his anger in all things, as now he led and army of Achaeans here in vain, and he went home to his dear fatherland with those ships, leaving here good Menelaus.

So someone will say; then may the broad earth gape open for me.

Aside from the typical expression of pain resulting from death (169170), Agamemnon's fear for his reputation and the fortune of the expedition after Menelaus' death is frequent in lamentation speeches, for the speaker is always concerned about the ramifications of the mourned figure's death, and expresses that eventuality in concrete, practical terms. ${ }^{39}$ Once more, the lamenter's fear for the immediate future is rebuffed, though this time Menelaus precludes lamentation on the purely practical grounds that the wound is not as bad as it looked (183-187).

Of course, this scene is not completely analogous to the first two examples, for the usual two-stage process has been collapsed into one, and PL takes place on the battlefield in an all-male setting. These unusual qualities do not, however, obscure the basic Gestalt informing and structuring the sequence; rather, they show the poet transforming the sequence for a circumstance where it is not usually deployed. ${ }^{40}$ Hence the male figure, who generally enjoys greater determinative freedom in Homeric epic, ${ }^{41}$ is surrounded by his hetairoi rather than the females

39 Tsagalis 2004, 30, 76-77, 115, 118.

40 Not only, of course, because it is on the battlefield, but because there are no female relations anywhere nearby - even Helen, the closest of his female kin in Troy, is no longer watching the plain - and lamentation is usually the preserve particularly of women; cf. Alexiou $1974=2002,10-14,21-22$.

41 Women are rarely 'there' in these scenes, and usually have to be moved into position in order to observe the matter which causes their lamentation: Andromache's surprising absence from the home is already commented upon tersely by [2] Hector (Il. 6.377-380; cf. Kelly 2007, 136-138; Stoevesandt 2008, ad loc., 122-123), whilst [3] Thetis has to hear Achilles' cries (Il. 18.35), [4] Hecuba is approached by Priam inside the house (Il. 24.193), and [6] Penelope by Medon (Od. 4.679-680), while [5] she hears the song of Phemius which causes her descent to the suitors (Od. 1.328-344). In [7] Penelope does descend into the house without hearing or being informed of something in the immediately preceding narrative, but she had earlier sum- 
of the household as in the other examples, yet they add their lamentation to his in the usual manner. ${ }^{42}$

\section{II.c The Pattern Specialised: [5], [7] and [8]}

The same pattern is evident, also with variations, in three examples of the sequence which all concern Penelope, and between which there is obviously a formal relationship, for they share a great deal of repeated phraseology, most notably their concluding three lines ([5] Od. 1.362$364=[7] 19.602-604=[8] 20.356-358)$, which represent the second, private stage of the PL sequence $:^{43}$

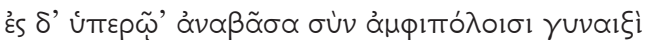

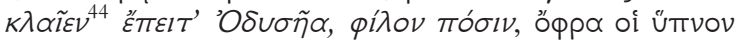

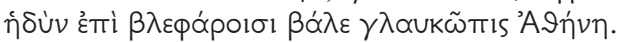

And going into the upper chambers with her attendant women she wept then for Odysseus, her dear husband, until sweet sleep was poured on her eyes by grey-eyed Athene.

In the first of these scenes [5], Penelope's exchange with Telemachus has several features of lamentation, including her tears before she speaks

moned the stranger to her $(O d .17 .528-551)$, though he had refused the meeting for reasons of propriety (i.e. the violence of the suitors) and suggested she wait until the 'setting of the sun' (17.569-570), which is what she does in this example at the start of Book 19. The bow contest around which [8] is constructed provides a much more expanded case, for Penelope is fulfilling the intention which she had voiced to the disguised Odysseus on the previous night (19.570-581, eagerly seconded by him $582-587)$ and which was put into her head by Athene on the day itself $(21.1-4)$, but which is in accordance with the instructions she received from Odysseus when he departed (18.259-271).

42 Compare Priam [4] who is surrounded by his family (male and female) as he grieves for Hector (24.160-168); cf. below, \ II (d), pp. 231-235.

43 [5] and [8] also share a repeated (and somewhat harsh) instruction from Telemachus to his mother preceding her departure $(1.356-361=21.350-354)$, and the opening of the scene is the same as well $(1.332-335=21.63-66)$. Wohl 1993, 42-43 traces between these scenes (and Alcinous' deployment of a very similar claim of authority $(11.352-353 \sim 1.360-361 \sim 21.352-$ $353)$ at his wife's expense) a program according to which "the differentiation of gender roles in the oikos is set in place".

44 Cf. Arnould 1990, 145-146. 


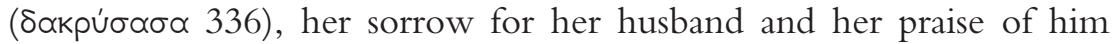
$(341-344),{ }^{45}$ all hanging on her description of the song as

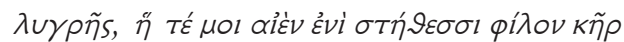

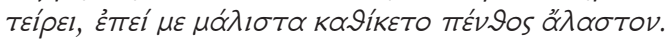

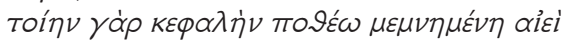

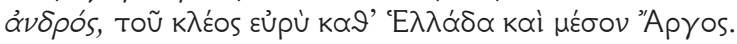

baneful, which always wears out the dear heart in my chest, since unforgettable grief has come on me in particular.

For I long for such a man, remembering him always,

whose fame spreads broadly throughout Hellas and the midst of Argos.

Moreover, she is (apparently) disappointed in her aim of preventing Phemius from singing about the Trojan War, for Telemachus sends her upstairs after asserting himself in a somewhat abrupt manner (345-359), and in terms which are repeated almost verbatim later on, in $[8] .{ }^{46}$ This repeated rebuff seeks to preclude Penelope's determinative freedom to mix with the men, denying her participation in public speech and then the bow contest $(1.358 \sim 21.352)$. Once more then, a dissatisfied female mourner, rebuffed about her actual fear or unhappiness, moves from the public to the private sphere where she continues or renews PL with the female members of her household. ${ }^{47}$

This rather contracted journey and private PL is repeated verbatim at the end of [7], a vastly expanded example shaping the famous interview between Odysseus and Penelope. After her husband's recollection of meeting 'Odysseus', Penelope breaks down in a memorable passage supported by lamentation elements (19.204-212):

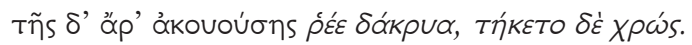

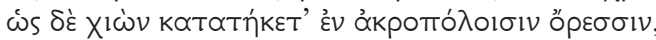

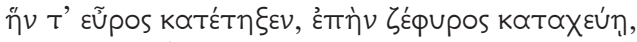

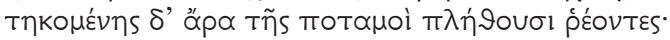

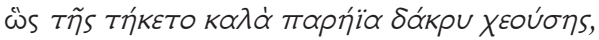

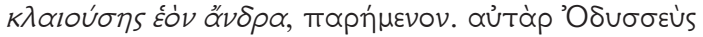

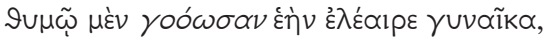

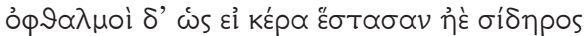

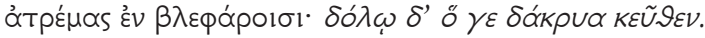

45 Cf. Tsagalis 2004, 28-29, 32-39, 44-45.

46 Cf. below, pp. 229-231.

47 There might be a question here over whether the attendants join in the lamentation but, given the typical context, I would very much doubt that we are in-

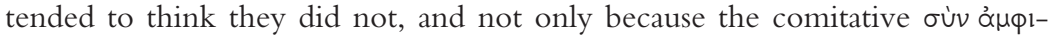

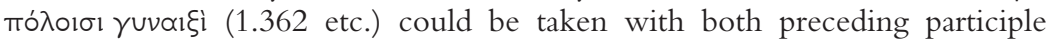
and following indicative in this repeated triplet. 


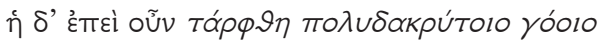

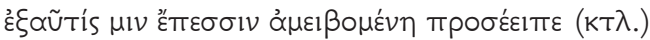

And when she heard this the tears poured, and her skin melted.

As when snow is melted down in the high-ranging mountains, when the east wind melts it, when the west wind pours it down, and as it is melted the rivers are filled with it in their flowing; so then were her fair cheeks melted as she poured tears, weeping for her husband, who was by her. But Odysseus in his soul pitied his wife as she made lamentation, yet his eyes stood as if horn or iron still in his eyelids; and with trickery he hid his tears. And when she had her fill of much-teared lamentation (etc.)

But it is not the end of her sadness $(249-252)$ :

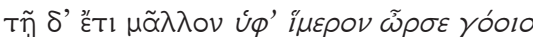

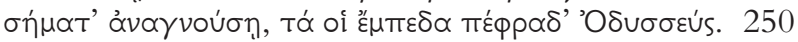

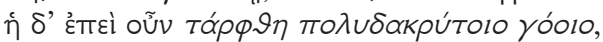

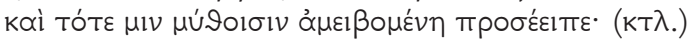

And still more she made rise the desire for lament recognising the symbols, which Odysseus had spoken to her. And when she had her fill of much-teared lamentation even then addressing him with speech she spoke: (etc.)

Similar elements are scattered throughout the rest of this extended scene, as for instance in Penelope's description of her sorrow and constant lamentation $(512-517,595-597)$. Though more gentle than his son, Odysseus no less seeks to rebuff his wife's feelings and fears (263-268):

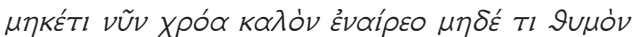

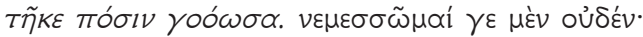

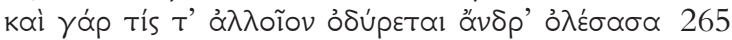

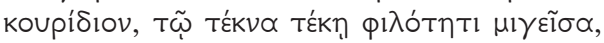

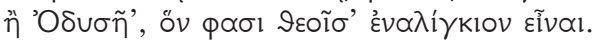

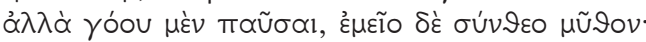

No longer now ruin your fair skin nor melt away your soul in lamentation for your husband; I find no fault in this, of course; For even another woman grieves that she has lost her wedded husband, to whom she has borne children laying in love, even if he is much less than Odysseus, whom they say was like to the gods. But come and cease your lamentation, and take thought of my speech: 
Moreover, he later urges her to set up the test as quickly as possible (582-583), obviously working here to hasten the very thing which will prove her fears unfounded.

Dissatisfied (to say the least) at the thought that she shall have to remarry as a result of the contest on the morrow (577-581), Penelope returns once more to her private quarters (600) for the final (private) group PL. Here the basic pattern is expanded considerably in order to accommodate the details of the interview and the famous recognition scene with Eurycleia. Nonetheless, the mourner's progression from public (rebuffed) PL to private group PL is recognisably the same.

The last of these three developed PL sequences [8] - also the last of Penelope's four total PLs in the poem - is a little more complex than even the last example, for the poet chooses to preface the sequence with another scene of private lamentation, as she goes into the storeroom to fetch the bow, where she is overcome with emotion (21.55-60):

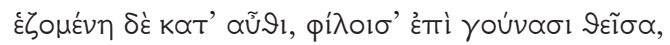

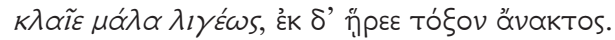

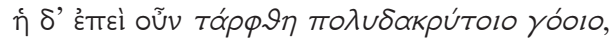

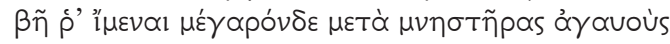

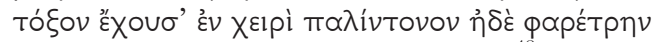

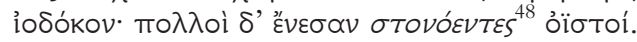

And sitting right there, placing it upon her own knees, she wept full loudly, and she took out the bow of her lord. And she when she had her fill of much-teared lamentation she went to go to the megaron among the lordly suitors holding in her hands the back-stretching bow and quiver that took the arrows; and there were many grievous arrows in it.

From here she descends (attended 63-66) with the bow into the house to set up the contest. In front of the suitors, she regrets her apparently necessary departure from the house $(68-79)::^{49}$

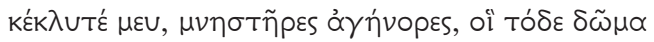

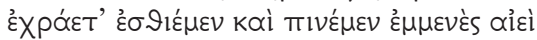

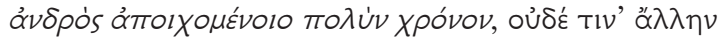

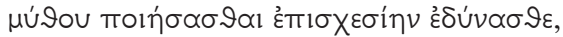

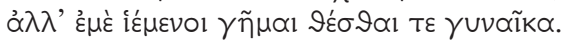

48 It is tempting to ascribe the epithet to the PL context (cf. also Od. 21.12), but

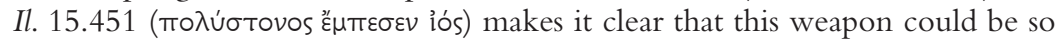
described outside the sequence, though the quality so described is particularly apt for the PL, or indeed lamentation in general.

49 Tsagalis (2004, 39-41 ('common fate' topos), 44-45 ('past and present' topos). 


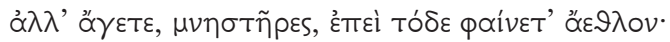

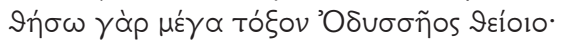

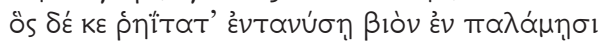

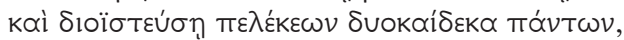

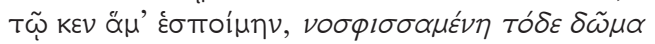

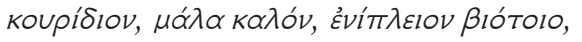

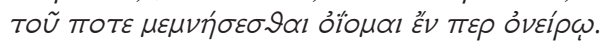

Hear me, lordly suitors, who have attacked

this house to eat and drink continuously

when my husband has been gone for a long time, nor can you

make any other pretext for your words,

but desiring to marry me and make me your wife.

But come, suitors, since this contest has appeared;

for I will set the great bow of godlike Odysseus;

whoever most easily strings the bow in his hands

and shoots through all twelve axes,

this man would I follow, leaving this house

of my wedded life, most fine, filled with life's means,

which I think I will remember even in a dream.

Note particularly the 'remembering' theme (77-79) and the earlier reference to the long absent Odysseus (70), ${ }^{50}$ though the clearest connotations of lamentation have already been deployed in the first scene, and the relative diminution in this section of the sequence - and its exchanges with the suitors - has everything to do with the fact that the test of the bow is to reveal Odysseus to the suitors, and to bring to its end her extended period of lamentation. ${ }^{51}$ After a long and varied narrative surrounding the contest, Penelope is dismissed once more by Telemachus in the now infamous terms, this time after she had become involved in supporting the 'beggar's' claim to participate in the contest. Such freedom, such a level of self-determination, is simply not appropriate for the Homeric woman. As her son says, these issues are properly the preserve of men. Having been dismissed in this way, Penelope re-

50 Cf. Tsagalis $(2004,36-39$ for the 'comparison' topos "used to differentiate the deceased from others who either belong to the same group of people or share a common bond with the lamenter" (38), but this should also be linked with the 'past and present' topos as well (44-45).

51 Hence she leaves before the contest takes place, which has always struck critics as rather unusual, given that it is she for whom they contend; cf. Fenik 1974, 162-163, who relates her departure and sleep to "the function of sleep ... : a major character sleeps through a long-awaited and climactic event and awakes to disbelief that the long hoped-for has actually happened." 
turns upstairs with her maids to mourn her husband once more in the typical way (356-358).

So here we have the same basic pattern of public PL followed by private PL, linked by a journey from the female figure after her fears or attitudes have been rebuffed, but preceded by another private scene in the storeroom. ${ }^{52}$ Like the previous two examples [5] and [7], the PL framework is used here to surround a much larger scene than normal (i.e., [1], [2] and [6]; also [3] below), with this time the various exchanges with the suitors over the bow contest, in which Penelope's role varies considerably, being generated between the PL's public and private stages.

\section{II.d The Pattern Transferred, Combined and Negated: [4]}

These last three examples show us how flexible the poet can be in adapting the sequence to particular narrative requirements, but the most untypical example is the Priam-Hecuba scene in Iliad 24 [4], which repays close attention, for its unique qualities actually serve to show how typical and established is the usual sequence, ${ }^{53}$ and in several respects it provides a close analogy for Thetis' scene. The episode begins with Iris' arrival (as with [2] Hector and [6] Medon), where she finds the Trojans engaged in some fairly extravagant mourning, and Priam in their centre $(160-168)$ :

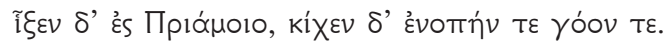

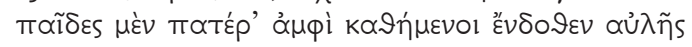

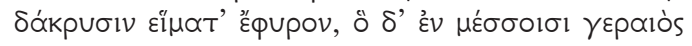

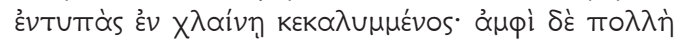

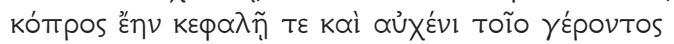

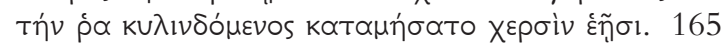

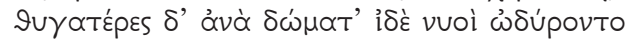

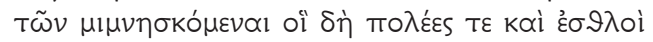

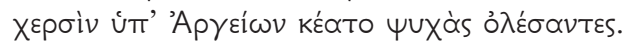

And she came to Priam's house, and found there crying and lamentation. And his children sitting around their father within the court were making wet their clothes with tears, and he in their midst the old man closely wrapped in his cloak; and about much

52 Cf. the role of the bedroom / storeroom (Il. 24.191-2, 228) in [4] below, $\mathbb{I}$ II (d) pp. 231-235.

53 On [1] cf. above, \ II (b), pp. 224-226. 
dung was on the head and neck of the old man which he piled up, rolling around, in his own hands.

And his daughters and daughters in law mourned remembering those many and noble men who lay having lost their lives at the hands of the Argives.

The mourning elements here are too obvious to require elucidation, but in the typology of the PL sequence, this scene corresponds to the usual group lamentation which (as we have seen) normally occurs in a private setting. Of course, this is a private setting, for Priam and his family are

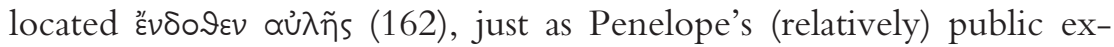
change with Medon [6] occurs on the threshold of the female quarters and not out in the larger space of the megaron.

Nonetheless, this example is different from that one, and indeed most of the rest of the examples, in two ways: (1) the usual progression from (individual) public lamentation to (group) private lamentation has been reversed, and we now begin with the second stage. Why the poet does so will prove to be of great interest for our analysis in the next section, ${ }^{54}$ but for now we can note that the poet wishes to have Priam (the chief mourning figure in this first scene) exit Troy for the famous episode in Achilles' tent. In every other PL sequence, the poet places the mourner into the private setting and then leaves her there, so the reversal here enables him to grant the mourner further participation in the narrative; (2) the prospective nature of the lamentation has also been altered, for Hector is in fact dead. ${ }^{55}$ The connection between actual and prospective lamentations will be also considered later in this article, but we observe here that in this case the group $(\mathrm{P}) \mathrm{L}$ is an actual lamentation for a dead figure which then motivates the individual exchange between Priam and Hecuba, the second stage in this PL sequence. This combination does not simply link the two narrative strands, though it certainly does that. More interestingly, it suggests that the predicate of the PL sequence - its inappropriateness - can also be found in situations where an actual lamentation is similarly unsuitable, but this time because the corpse, around which lamentation should be performed, is absent.

Priam's following exchange with Iris focuses on the reason why he should not fear death (171-187), and so provide him with the grounds to rebuff Hecuba when she delivers her personal PL. Her reaction to his intention, naturally, is somewhat reluctant in its import, and is once

54 Cf. below, \II (e), pp. 237-238.

55 Cf. below, \ III, pp. 246-247 n. 91. 


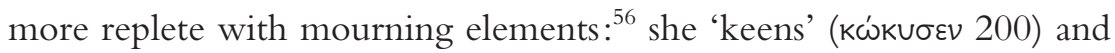
exhorts him to join her in mourning for Hector (208-209), before turning to his virtues and death $(209-216),{ }^{57}$ as well as her own famous wish for revenge $(212-214) .{ }^{58}$ Hence we see once more the bipartite structure of the sequence, but in reverse, with a private group lamentation (actual rather than prospective) followed by a PL exchange between the characters, though in the even more private setting of the house, and with a change of personnel (Priam - Hecuba) from the first part of the sequence.

As with the other cases, Hecuba's concerns meet with the typical and immediate rebuff from Priam (217-227), but the poet is not finished with the PL sequence. What is noticeable is that elements and features connotative of mourning then continue to appear in the rest of the scene, beginning with his reply to his wife. Picking up on Hecuba's desire for revenge, but referring the 'death-wish' theme more typically back onto himself, ${ }^{59}$ Priam insists on making the journey in terms which explicitly summon both the notion of goos and the frequent holding / touching of the corpse ${ }^{60}(226-227)$ :

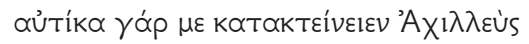

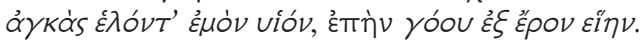

Straightaway let Achilles kill me

holding my son in my arms, when I lay aside the desire for lamentation.

He then descends into his house in order to gather the ransom and keeps 'all the Trojans' out with his stick and a stinging rebuke (237-238) which once more invokes typical themes of mourning and lamentation (239-246):

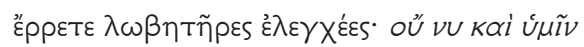

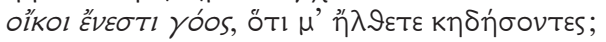

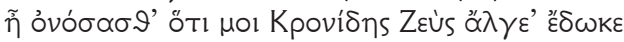

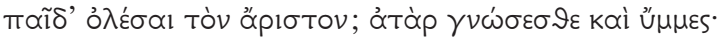

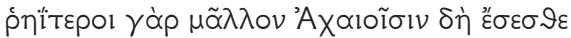

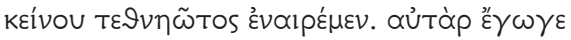

56 Cf. Martin 1989, 87-88.

57 Cf. Tsagalis 2004, 32-39.

58 Cf. Tsagalis 2004, 42-44 for the 'death wish' topos, here transferred from the mourner to the killer.

59 Cf. Tsagalis 2004, 42-44.

60 Cf. 18.316-317 (23.17-18) (Achilles for Patroclus), 23.135-137 (Achilles for Patroclus), 24.710-712 (Trojan women for Hector), 24.723-724 (Andromache for Hector). 


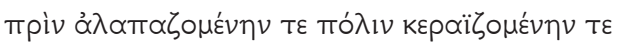

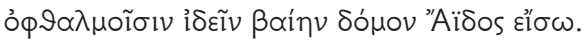

Begone, wretches, reproaches; is there not for you too

lamentation at home, that you have come to me to grieve me?

Do you find fault that for me Cronus' son Zeus has given me grief

to lose my best son? Even you will know it.

For you will be much easier for the Achaeans

to kill now that he is dead. But I

before I see with my eyes my city taken and ravaged

may I enter into the house of Hades.

Again, though this time in a setting of reproach, Priam invokes the characteristically lamentatory ramifications of Hector's death for the mass of Trojans $(243-244)^{61}$ who are seeking to mourn with him (240), telling them in effect to express their own grief in their own homes. This plays cleverly off the usual process of moving between the public and private spheres, for Priam not only prevents the Trojans as a whole from forming a mourning group, but he does so again to his own family, scattering and rebuking his surviving sons, while lamenting the death of his more favoured offspring (253-264). The dismissed group is even catalogued by name (compare [3] the list of Nereids in Thetis' scene), but only for its unworthiness to be present at any mourning process!

Homer has here transformed the usual PL, and in several ways: (1) he has reversed the public-private sequence; (2) chosen to begin with an actual group lamentation for Hector; (3) placed Hecuba's individual PL in an entirely private setting; and (4) generated two further, cancelled, scenes of group PL, one directed at his family, the other at the Trojans as a whole. This cancellation is profoundly metapoetic, for the poet hereby acknowledges his audience's expectation, after Hecuba's first speech, of a further group PL in a more private setting; hence he generates several of the typical elements but only and specifically in order to cancel them out - twice. In some ways, of course, he didn't need the group reaction, for he began the sequence with an actual lamentation (24.160-168), and the poet has no intention of stopping Priam's further participation within the narrative in his usual way.

This extraordinary, virtuoso scene is only possible because of the audience's expectations of the PL sequence. As if finally to confirm the way in which he has played with, indeed inverted and frustrated, those expectations, Homer closes the scene by returning to a sorrowing

61 Cf. Tsagalis 2004, 44-45. 


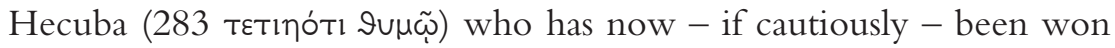
over to his mission, as long as Priam gains the requisite omens from Zeus (286-298). Her shift in attitude, however qualified, symbolises the inversion of the PL as usually practised, but the poet makes sure that he doesn't entirely defeat the sense of danger which Priam faces by having him drive out of the city to the accompaniment of his sorrowing philoi (327-328):

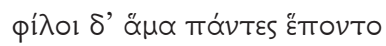

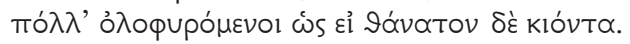

And all his friends followed

grieving much as though he were going to death.

This is of course a tremendously complex and sophisticated example, but other less radical variations are possible, as for instance we have seen with Agamemnon's PL for Menelaus [1], in which not only are the (elsewhere separate) public individual PL and the private group PL combined in the one example, but also the chief mourner is a male; and we might remember [7], where a considerable amount of narrative separates the initial public PL from the final private PL, and the whole sequence is actually the frame for the encounter between Odysseus and Penelope; or even [8], where an extra scene of private grief precedes the usual sequence and largely takes over lamentation elements from the following public stage of the sequence, but is also the vehicle for a larger sequence of narrative, the introduction of the bow test.

These exceptions are meaningful because of the rule they presuppose - to be crude and deterministic for a moment - that a PL delivered by a female in a public setting is rebuffed and then followed by a PL delivered in a private setting by the same female in company with the members of her household. Though this is not a typical scene in the same sense as the famous arming scenes, there is a consistent sequence across the examples, next to which the variations gain their meaning and significance. Having established the form of that sequence and discussed its instantiations in both Homeric poems, we can now claim a sufficient familiarity with the poet's technique to address Thetis' famous lamentation. 


\section{II.e The Pattern Applied: [3]}

Seen against its typical background, it should have caused neither consternation nor wonder that Achilles is mourned before his death, and on his own terms. ${ }^{62}$ Such a scene should not be considered less appropriate (vel sim.) than a scene of actual lamentation, and not merely because most of these PLs do not correspond to any such episode in the (admittedly scanty) records of early Greek epic. ${ }^{63}$ In the broadest of terms, Thetis' PL for Achilles is an example of a fully typical and amply paralleled sequence within Homer's compositional technique, and as such requires no external explanation to account for its presence in the Iliad. As with the other examples, we have a two-stage process of female lamentation, with public $(65-145)$ and private $(35-64)$ stages, along with a rebuff from the bemourned figure $(97-126)$. In failing entirely to recognise the existence of this framework, the Neoanalysts and their adherents have failed to take adequate account of the traditional nature of Homeric poetry. ${ }^{64}$

62 Much has been made of the fact that Patroclus is dead (e.g. by Kullmann 1981, 23; 1991, 441; also below, n. 64), and yet the motifs for lamentation associated with Thetis and the Nereids are directed towards Achilles; cf., e.g., Danek 1998, 470: "Achills symbolisches Sterben im Tod des Patroklos wird noch hervorgekehrt, wenn die Nereiden eine Totenklage um den um sein alter ago trauernden Achilleus anstimmen". The widespread scholarly conclusion that their lamentation has been transferred to him from the actual corpse is nothing more than a failure to recognise the conventions of this sequence. The poet connects Thetis' PL for Achilles with the preceding actual lamentation for Patroclus, but they do not cross over: neither Thetis nor the Nereids engage in lamentation for Patroclus anywhere in this scene (though Thetis 'rouses the goos' for Patroclus later (23.14), which has also been grist to the Neoanalytical mill; cf. Kakridis 1949, 84; Richardson 1993 ad loc., 167 with Burgess 2009, 90; Dowden 1996, 59), nor should we expect them to do so.

63 Cf. further below, \III, pp. 245-248.

64 Cf., e.g., Pestalozzi 1945, 32: "Das Leid der Göttin gilt in der Ilias nicht dem gefallenen, sondern dem todbedrohten Achill; das bedingt wesentliche Änderung. Der Thetis Erscheinen zur Totenfeier ist umgebildet in den Besuch bei dem leidbeschwerten ... Die Totenklage ist abgebogen auf den noch lebenden ..."; Kakridis 1949, 69-70: "One cannot get rid of the feeling that Thetis' róos - a word which signifies particularly death-lament - and her sister's anguish would be more appropriate to a scene representing the Nereids as mournling a dead man... There can be no doubt: both the motif of lamentation and Thetis' gesture would be incomparably more natural in a scene of funeral lament over Achilles' dead body"; Kullmann 1960, 37: "das Gesamtthema einer 'Klage um das Unglück eines Lebenden' (ist) als Umformung des einfachen 
But the devil is, as always, in the details, and the notion of $\mathrm{PL}$ as a typical sequence only provides the starting point for our exploration of this episode, and our response to the Neoanalytical case. We begin by observing that Thetis' scene inverts the usual order: here the private PL with the Nereids is followed by a public individual PL in the form of an exchange with her son (with the Nereids in the background). One might be tempted modo Neoanalytico to seek an external explanation for this (almost) unique variation, yet we have already seen the poet do much more adventurous things with the pattern than simply reverse the order of its two basic constituents, and surely no-one would argue from its individuality that, e.g., the complex Hecuba-Priam scene [4] is derived from (or alluding to etc.) the Iliou Persis or its material. ${ }^{65}$

Nonetheless, we still have to explain the poet's decision, and once more the unique situation of the narrative that gives all the explanation and motivation required. Firstly, in the other developed (i.e. two stage) PLs (i.e. [2], [5], [6], [7] and [8] above) the poet leaves the female figure in the private sphere amongst other females, and moves elsewhere. If the narrative stays in this context for any length of time, the prospective mourner is involved in further action inside that private sphere (e.g., [6] Penelope prays to Athene), ${ }^{66}$ but does not leave it.

Themas der 'Klage um den toten Achill' auszufassen”; Kullmann 1981, 23 : "Wenn im $\Sigma$ auf das Schreien des Achill hin sich die Nereiden bei Thetis versammeln und mit der Totenklage beginnen, obwohl sie nicht wissen, warum Achill schreit, und obwohl sie zu Patroclus keine Beziehung haben, so ist klar, daß hier das Motiv der Totenklage ohne Detailüberarbeitung in die Ilias übertragen ist"; Burgess 2009, 83-84: "Thetis and the Nereids perform mourning rituals in their cave for no other reason than that Achilles has cried out ... the misplacement of funeral elements here is remarkably sustained ... the unusual behaviour of Thetis and the Nereids goes beyond grieving and unusually mimics the rituals of a funeral" (my italics).

65 Cf. below, S III, pp. 246-247. Indeed, we have reached a very strange pass in Homeric scholarship, when anything which can reasonably be considered special or individual - that is, the kind of thing which used to be read as the poet's own contribution - becomes instead the traces of his sources or poetic predecessors.

66 One need not argue that the PL pattern itself 'forced' the poet to move away from such scenes, rather than acknowledging that he had generally less interest in developing that - particularly female - context. There is, in fact, no case in either Homeric poem in which a female character, having been placed into that context from a public setting, actually leaves it in the same sequence of narrative (the arming scenes of Athene in Iliad 5 and 8 are no exceptions, for they are arming scenes and predicated on the immediate deployment of the equipment). 
In Thetis' scene, by contrast, the poet had no intention whatsoever of leaving her after the PL, but was preparing to have her journey to Olympos for one of his signature scenes, the making of Achilles' armour. For Homer to follow his usual order in this case - which would mean Thetis going from her father's house to Achilles for her public PL, returning to her father's abode for a private PL, and then setting off again immediately for Hephaestus' house before returning to the Greek camp with the new armour - would be intolerably clumsy, and unparalleled elsewhere for divine travellers in the Homeric epics. ${ }^{67}$ By bringing her instead from private lamentation inside her father's house to the public space of the Greek camp, the poet ameliorates that potential awkwardness, and leaves Thetis free to travel subsequently wherever he requires. It is the most convenient way, given his narrative habits, for Homer to create the possibility of her further involvement in the story. ${ }^{68}$

Crucially, we have already observed the poet doing exactly the same thing with the Priam-Hecuba scene [4], where the reversal leads similarly into Priam's involvement in the rest of the book's narrative. ${ }^{69}$ In that case, the chief character is of course not as subject as Homeric women to the restrictions of the house, though it is interesting that the scene is set entirely within the confines of his palace. Nevertheless, the poet did not simply want to end with Priam lamenting as part of a larger group, and even went so far as to cancel out two such opportunities to do so. The reversal of the sequence in both of these cases shows that the poet's eye is on the character's future participation in the narrative.

In doing this, however, Homer also creates the 'problem' of having Thetis mourn among her sisters before she hears of what Achilles is about to do, i.e. before she 'knows' his intention to kill Hector immediately,

67 The case of Poseidon's journey from Samos (across from Troy) to Aigai, and then by his chariot back to a cave near Troy (Il. 13.11-38), is not of the same order: (i) the chariot journey has a literary, cultic and narrative significance (cf. Janko 1992, 43) which justifies its slight geographical awkwardness; and (ii) none of the places on his itinerary are identical.

68 It has also a structural advantage, in that the poet thereby creates a most pleasing ring in her travels, from (a) her father's house under the sea to (b) the Greek camp, then to (c) Olympos, and then back to the Greek camp (b) before returning (a) to the sea. Though this last stage is omitted from the poet's description, where else would she go? When we next see Thetis at the start of Book 24, that is where she is.

69 Cf. above, \ II (d), pp. 231-235. 
which will necessitate his own death rather soon. ${ }^{70}$ Usually, of course, the private PL mourns the very thing the individual has learned during the public PL, and so one might simply invoke the pattern's reversal for leading the poet into this (really rather slight) narrative undermotivation. Yet several factors suggest that it would be wrong to make too much indeed anything - of this fact, for Homer goes to great lengths to accommodate his choice within his narrative, and makes much semantic play therewith.

Firstly, it is typical of Thetis' character throughout the Iliad that she is constantly in mourning for Achilles' coming death. When she first appears in Book 1 she is again depicted comforting him and, upon learning of the details of her son's distress, cries (413) and bemoans the awfulness of her situation as a mother $(414-418) .{ }^{71}$ This plaint is repeated several times and in several forms, from her insistence to Zeus that her son 'is the swiftest to die of others' $(1.505-506)$ to the description of her state to Hephaestus (18.428-443). Even Zeus acknowledges her emotional situation, sympathetically praising her for the journey to Olympos in spite of the fact that she is 'mourning, with terrible grief in your heart' (24.104-105). She is granted a particular and continuous status of anguish in the poem, and its source is the fact of her son's death.

Indeed, this is what she particularly fears in her speech to the Nereids in the cave, which does not depend in any way on the knowledge she gains from Achilles in their subsequent exchange. ${ }^{72}$ This is her major

70 This has been a particular mainstay of Neoanalytical criticism; cf., e.g., Kakridis 1949, 69: "that his hour of death has come the goddess will conjecture only in the following scene, when she sees her son determined to take vengeance on Hector"; Kullmann 1960, 36-37: “die grösste Unebenheit besteht hier ... darin, dass die Klage der Thetis und der Nereiden einzig durch das | Jammern Achilles ausgelöst ist, für das man den Grund noch nicht kennen kann, im Unterschied zur Aithiopis, wo Thetis um das ihrem Sohn bevorstehende Geschick weiß"; id. 332: "das überraschende ist, daß Thetis und ihre Schwestern gar nicht wissen können, was dem Achilleus zugestoßen ist and daß etwa durch den Tod des Patroclus nun auch der Tod des Achilleus selbst naherückt"; Burgess 2009, 84: “... the unusual behaviour of Thetis and the Nereids ... is not motivated, for it precedes the conclusion of Thetis that Achilles will soon die".

71 Indeed, Schoeck 1961, 40-41 and 43-44 tries to link this scene with the mourning scene at the start of Iliad 18 as the split manifestations of the Memnonis scene on which he believed Homer depended.

72 This is entirely missed by Kakridis 1949, 69: "the fact that during his short life he has to suffer again and again fresh sorrows - and what this new grief is his mother does not know yet - can hardly justify this excessive anguish". Edwards 1991 ad 18.63-64, 152 sympathetically remarks that "Thetis' ignorance here 
characteristic in the poem - her grief comes not from the usual mortal fear that her beloved may be in imminent danger of death, but from her particularly immortal certainty that her son will die in Troy. ${ }^{73}$ As late as Book 24 she can be depicted under the sea and surrounded by her sisters, just as she is at the start of Book 18, mourning Achilles' doom (24.83-86):

عن̃

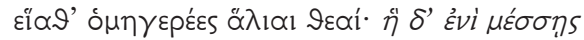

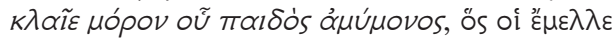

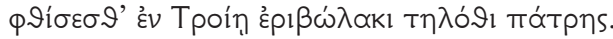

And she found Thetis in her hollow cave, and round her there sat gathered the other goddesses of the sea; and she in their midst

bewailed the doom of her own son, who was soon

to die in Troy of the fertile earth far from his fatherland.

One might try to refer this to the scene in Book 18 as merely an 'internal allusion', or even explain it as less problematic because Thetis has now gained more definite knowledge about the imminence of Achilles' death (18.95-96; see below, however) ${ }^{74}$ Neither argument is convincing, for the mere fact of repetition shows that Thetis could naturally be depicted in a semi-permanent state of mourning for her son well before his actual death, and the pervasive theme of her particular suffering easily and fully motivates scenes of this sort. It is absolutely in keeping with both her character and her situation in the Iliad that she should be constantly preoccupied with Achilles' doom, so we should not be surprised to see her acting thus before she hears of his decision to return to the battle. In short, there is no reason to believe that her first speech of lamentation is poorly motivated or ill-suited to the situation of the Iliad, or that it would be better suited to another poem or story. ${ }^{75}$

With Thetis' behaviour and attitude thus contextualised, we should turn to the Nereids themselves, whose function is also illuminated by

(and at 1.362) of Achilles' troubles, despite her prophetic powers (9-11, 17.408-409), is of course adopted so that Achilles may voice them to her himself', though her ignorance of his current misfortune is simply natural, given that her general motivation for grief over Achilles is a constant, and not caused by his current anguish for Patroclus.

73 Cf., e.g., 9.410-416, 17.404-411, 21.276-278; also below, pp. 249-252 for the limits of her knowledge.

74 Kakridis 1949, 69 n. 7.

75 That it might be also (or even less) suited to another text, poem or story cannot, of course, be denied; cf. below, pp. 245-248, 252-254. 
the PL framework. ${ }^{76}$ As in scenes of actual lamentation, the mourner's speech or activity is set off next to a larger group - Agamemnon's male comrades [1], handmaids for both Andromache [2] and Penelope $[5],[6],[7]$ and $[8]$, Priam's family $[4]^{77}$ - so that the presence of the Nereids at the start of Iliad 18 is actually required, or at the very least extremely well paralleled, in similar settings. Given Thetis' abode with her father, ${ }^{78}$ her sister Nereids are as natural a choice for her group as are Agamemnon's comrades or their maids for Andromache and Penelope. ${ }^{79}$ Their gathering, presence and purpose in the cave is readily accounted for within the PL sequence.

Perhaps, however, we still need to explain why they come to the camp as well, where they apparently perform no function, being mentioned only at the start and end of the scene $(65-69,137-145) .{ }^{80}$ Once

76 Lohmann 1970, 141-145 points out the careful ring structure governing this scene, in which the Nereids form the outermost part, and which centres on Thetis' prediction (below, pp. 249-252; table from Lohmann 1970, 142):

I. Thetis kommt mit Nereiden (65ff.)

II. Einführende Rede der Thetis (73ff.)

III. Achill $79 / 93$

IV. Thetis $95 / 6$

V. Achill 98/126

VI. Abschließende Rede der Thetis (128ff.)

VII. Thetis entläßt die Nereiden (140ff.)

77 Though, as we argued above (pp. 233-235), the poet actually cancels out, twice, the notion of elaborate group mourning after Hecuba's initial PL; I refer here mainly to the depiction of Priam surrounded by his family at the start of the scene (Il. 24.160-168).

78 That is, after all, where she is every time the poet brings her into his narrative: she has to be summoned from there to her son's side $(1.357-358)$, she journeys from there to Zeus and back again $(1.495-497,531-532 ; 24.83-86)$. This is not inconsistent with the several references to her living with Peleus after their marriage $(1.396-397,16.573-576$, ) or being in Phthia at the moment of Achilles' departure (16.220-224) or return (18.59-60,330-332, (impossibility thereof) 19.421-422), for none of them need mean that she was still living with Peleus at the time of the Trojan War.

79 Note that their lamentations are always marked by the term goos, the term deployed for lamentation uttered by the kinswomen; cf. Alexiou $1974=2002$, 11-14; Tsagalis 2004, 2-8.

80 Kakridis 1949, 67 “... the Nereids come and go without taking part in anything”; Pestalozzi 1945, 32: “die Nereiden (haben) - im Gegensatz zur Vorlage - in der Ilias keine Aufgabe ... nach dem Zwiegespräch, das sie nicht durch ihre Anwesenheit stören, werden sie von Thetis gleich wieder heimgeschickt ...”; Schoeck 1961, 44: "ein deutlicher Fingerzeig war vor allem $\Sigma 65$ ff. die Anwe- 
more the PL's reversal can be invoked as the first line of explication: the second stage of this sequence usually demands a group, and we could argue that the poet felt the presence of the pattern so deeply that he brought them along in order to preserve the associations of a scene which he was generating in such an individual manner, simply to make it clear that this was still a scene of PL (as, indeed, we observed earlier with the Hecuba-Priam scene [4], the uniqueness and complexity of which was far greater).

It is hardly unthinkable anyway that the larger group should be present, since they are after all a typical feature in scenes of lamentation. ${ }^{81}$ As we saw above, the poet constructs the public stage of the PL by generating mourning elements within and around the speeches of the participants in a (more) public setting. The presence of the Nereids in the Greek camp could easily be one of these elements, and the uniqueness of a group presence in this stage of the PL (leaving aside the mixture of public and private evinced in [1]) would then be ascribed to the extraordinary nature and importance of Achilles as the poem's central hero. After all, group participation in actual funerals reflects the importance of the mourned figure, as the Trojans as a whole mourn Hector, while 'mountain nymphs' plant the trees around Eetion's tomb (Il. 6.419420), and as Thetis, the Nereids and the Muses mourn for Achilles himself (see above). ${ }^{82}$ So the Nereids are another signal of Achilles' pre-emi-

senheit der Nereiden beim Mutterbesuch”; Burgess 2009, 83: “... the Nereids oddly accompany her (65-9). They do not participate in the private conversation that follows and have to be rather awkwardly dismissed at the end of the scene." Somewhat differently, Tsagalis $(2004 \mathrm{a})=(2008)$ argues that, because the Nereids are first depicted in the cave as beating their breasts $(18.50-51)$ and crying as they journey to the camp (66), this scene shows "a movement from excessive lamentation to restrained grief ... not observed in any other Iliadic lament" which supports its 'extratextual' relationships. But this scene is also the only case where the PL mourning group actually moves out of the private sphere, and so they must show their mourning status by crying (viz. something possible when moving) rather than by the ritual action which takes place only when one is placed around the object or leader of lamentation.

81 Indeed, they are even present in [1] (above, $\$ II (b), pp. 224-226); cf. also Edwards 1991 ad loc., 152.

82 Cf. Kirk 1990 ad loc., 215. I am not conceding that the Thetis scene must be a reference to his actual death lamentation. Homer clearly knew that story, for which he gives the Muses as the professional singers of the thrennos in Odyssey 24 , but the choice of the Nereids in both his prospective and actual lamentation is demanded by the simple fact that Thetis is his mother, and needs a household group next to which her mourning can be generated. Though the scenes are 
nence in the Iliad, and they literally surround Thetis' public PL as Priam's philoi surround him [4]. ${ }^{83}$

But there is a much easier ground on which to 'explain' the presence of the Nereids in the Greek camp, and this is that when a female mourner is outside the house or the female quarters of the house in a scene of PL, she is always accompanied in that (more) public sphere by members of her household: ${ }^{84}[2]$ Andromache is attended by a nurse with her son (Il. 6.399-400); [5] and [8] Penelope is attended by two unnamed serving women $(\mathrm{Od} .1 .332-335=21.63-66),{ }^{85}$ and [7] by Eurynome, Eurycleia and two anonymous serving women as she leaves the scene (Od. 19.600-602) ${ }^{86}$ even [4] Hecuba is so attended as she appears in the courtyard of Priam's house to bestow her qualified blessing (Il. 24.302-305).

Such an accompaniment is natural for mortal women in Homeric poetry, yet the immortal Thetis neither needs nor does she elsewhere

integrally related on the level of story and character, there is no reason why their presence in one scene (or the other, for that matter) must or should be explained as derivative from another scene, at least on the level of that story's realisation.

83 Cf. above, n. 76, for Lohmann's demonstration. Neoanalysts have been attracted by the fact that the Nereids have no relationship with Patroclus (cf. above, nn. 62 and 64) and yet they seem to be involved in mourning him. However, and this cannot be stressed enough, Homer nowhere states that they became involved in that process: their function is limited to, and explained by, the PL for Achilles.

84 Penelope [6] is approached in the house by Medon with the news of Telemachus' departure (Od.4.679-680). That Agamemnon [1] also has his hetairoi around him is natural in another way, given their situation on the battlefield, but it is also to be explained by the needs of PL, in that his speech is immediately linked with the mourning reaction of his group (above, pp. 224-226).

85 Cf. above, S II (c), pp. 226-231, for other structural parallels between these two scenes.

86 No attendants are mentioned at the start of [7] when she emerges from the private quarters to interview Odysseus (19.53-59), though some unidentified fig-

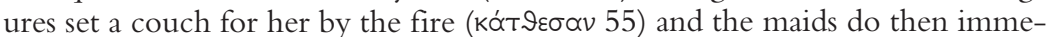
diately come 'from the megaron' to clean up after the recently departed suitors (60-64). However, upon hearing Odysseus' exchange with Melantho and rebuking the latter (65-95), Penelope does give instructions to her tamie Eurynome (96) and, later on, to Eurycleia (357 and ff.), so we should not assume that she was unattended throughout the scene, nor should we forget this scene occurs at night after the departure of the suitors (18.427-428), when Penelope is left alone with the serving women - and Odysseus - in her own house. 
travel with attendants. ${ }^{87}$ Nonetheless, as we have seen, a large part of the point of putting her into the PL sequence is to show, by comparison with the usual mortal participants, the uniqueness of her situation. Homer's decision to present Thetis at the centre of this PL underlines her divinity at every stage, and the resulting narrative is profoundly shaped by that fact. She does everything that mortal females do, and some things they do not, but always with the greater power and potential appropriate to a goddess: she mourns more constantly (at least in the Iliad); she emerges from the private setting to assume an important role in the subsequent narrative; and she travels into the public setting with more, and more impressive, attendants. ${ }^{88}$ If the Hecuba-Priam scene [4]

87 At least, not in Homeric epic. In Archaic art, by contrast, Thetis is constantly depicted in the company of the Nereids. Cf. Barringer 1995, 169: "the Nereids $\ldots$ are revealed as benevolent, protective escorts or attendants for individuals undergoing two critical life transitions, marriage and death, which are manifested as either literal and/or metaphorical journeys"; cf. also ead. 1995, 54-58 for a discussion of the widespread association between the Nereids and death, in which they frequently served as attendants or escorts, reaching a spectacular form in a (probably) 4th-century BC tomb structure widely known as the 'Nereid monument'. If such associations or functions were known to the Homeric poet, then they were even more suitable figures to accompany Thetis to the Greek camp.

88 It is interesting that this or a very similar scene of PL seems to be reflected on a Corinthian black-figure oinochoē c. 570-50 BC (LIMC 'Achilleus' 478), where Achilles is lying on a couch and brings his hand to his head in a typical gesture of mourning. At his feet stands Thetis, at his head someone who may be Phoenix (Barringer 1995, 27-28); behind Thetis is Odysseus and a woman, and behind Phoenix two women. These females may be Nereids, though Kossatz-Deissmann (LIMC) plausibly suggests that they are Briseis and slaves. Whatever their identification, it is clear that the scene must represent a PL for Achilles, whether independent from the Iliad or not: though alive, he is in the standard position for a figure being mourned, whilst himself performing a mourning gesture; the standing figures around the couch are typical for such scenes; $\mathrm{cf}$. Barringer 1995, 27, and Lowenstam 2008, 33-35, both of whom opt for a synoptic interpretation of the scene. Artistic representations should not simply function as evidence for the history of Greek epic (Lowenstam 1997; cf. also 2008 esp. 1-12,170-173), but it is tempting to conclude, despite their differences, that the Iliad's scene made this impression. In any case, it is striking that there is only one known early representation of the actual lamentation for Achilles, also by the same painter (Barringer 1995, 52-53; Lowenstam 2008, 18-19, 3335), on a Corinthian black-figure hydria c. 570 BC (LIMC 'Achilleus' 897), and this presents several named Nereids, and one female figure holding a lyre. If the Aethiopis (vel sim.) scene was so well-established as to warrant Homer's deployment of or allusion to it in the Iliad, that prominence is hardly evi- 
showed us Homer creating narrative by reversing or denying the suggestions and connotations of the PL sequence, Thetis' scene is his most exceptional realisation of its narrative possibilities.

I submit, then, that PL is the typical framework governing the form and function of the mourning of Thetis and the Nereids at the start of Iliad 18. The two stage pattern, and the reversal of its constituent elements, explains the ante mortem lamentation of Achilles, the behaviour and attitude of Thetis, and the presence of the Nereids in both the cave and the Greek camp. The resulting sequence highlights the extraordinary character and circumstance of Thetis, and so the extraordinary nature of the son for whom she prospectively mourns. There is nothing inexplicable or poorly motivated here, and nothing which would be better motivated in another text / poem / story than it is in the Iliad. Once we realise that there is a typical sequence underlying this episode, there can be little reason to follow the Neoanalysts in requiring an external source of any sort to account for, even especially to illumine, this section of the narrative.

\section{The Future}

To the preceding demonstration and conclusion, one could of course respond that a PL naturally looks forward to an actual lamentation (AL), as for instance Andromache's PL for Hector [2] finding its complement in the ALs of Andromache (22.467-515) and then Andromache, Hecuba and Helen (24.719-776) for the same figure. Therefore, no amount of pointing out the typicality of the action, and its significance within the Iliad itself, could deny the possibility that the audience is still being reminded of Achilles' funeral. In fact, this cannot and should not be denied, for the poet goes to some lengths to connect the deaths of his major characters in a causal chain stretching well beyond the Iliad, and it is anyway inconceivable that any early Greek au-

denced in the artistic tradition. This gives at least some reason to wonder at the cogency of the Neoanalytical case, which relies so heavily elsewhere on the evidence of Archaic art. 
dience had never heard performances of the same or similar material before they encountered this version of the story.

But there is still a question of the role which that dynamic plays in the scene, and the level of importance which it is to be accorded, and this is where the consideration of the sequence's typicality becomes essential. Neoanalysts have traditionally claimed that an external episode is necessary for an understanding of the scene,${ }^{89}$ but if such a connection were inevitable or fundamental, one might expect to find a similar dynamic in all the examples of PL we have identified, as for instance in the Hecuba-Priam scene [4]. Priam's death has indeed been reconstructed by Kullmann on the basis of scattered references throughout the Iliad, ${ }^{90}$ but one labours in vain to find any allusion to the form of that event as found in Proclus or elsewhere in early Greek myth (Iliou Persis arg. 13-14 Bernabé; Ilias parva F 16), rather than to the immediate situation facing Hecuba and her husband: Hecuba fears his journey to the Greek camp and the savage nature of Achilles (203-208), exhorting him to mourn his son (209-212), before expressing her desire to eat into her son's killer (213-216). Priam's response focuses on the need to trust the gods who have informed him (218-224) and expresses a willingness to die in the Greek camp holding his dead son in his arms (225-227). It would serve no purpose to paraphrase the rest of the scene in this way, since even Kullmann finds no support in this extended and varied PL for his conclusion that Homer knew "eine detaillierte Darstellung von Priamos' Tod". ${ }^{91}$ There seems to be no allusion in this

89 This is a logical extension of the detection of problems or difficulties in Homer's text (above, $\mathbb{S}$ I, pp. 213-218), but more recent authors, by refusing to use this kind of terminology (though not universally, and generally without abandoning the conceptual framework; cf. above, nn. 19-20), have deprived themselves of that progression. Therefore, it is hard to see what that does except to reduce their argument to the contention that the Homeric episode can also be explained by such a reference.

90 Kullmann 1960, 348-349. Of course I feel that this reconstruction is in every way tremendously overconfident (despite the welcome caution expressed id. 348 n. 2).

91 Kullmann 1960, 349. We should also note that, like our target scene, [4] is not only motivated by an actual lamentation, but it incorporates that AL within its sequence, as we saw (above, $\mathbb{S}$ II (d), pp. 231-235). Thus we can infer that, had the poet wished to blend the AL for Patroclus with the PL for Achilles in Thetis' scene (as many have concluded; above, nn. 62 and 64), he could have done so. He did not. 
PL to Priam's eventual death in the destruction of Troy, or to any lamentation which may (or may not) have occurred there.

The same is true of those PLs which concern similarly prominent figures in early Greek epic, such as Odysseus [5], [7] \& [8] and Menelaus [1]. Both characters have their deaths explicitly mentioned by Homer, the first in Teiresias' famous prophecy that death will come 'gentle ${ }^{92}$

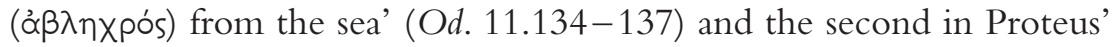
prophecy of his translation to Elysium in terms which apparently pass over entirely the usual processes surrounding a mortal death (Od. 4.561-569):

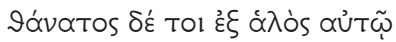

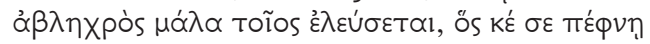

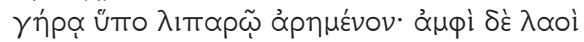

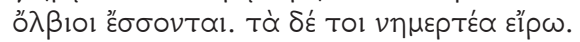

And death will come to you from the sea very gentle, which will kill you taken by rich old age; and about you the people will be blessed; these things do I speak to you truly.

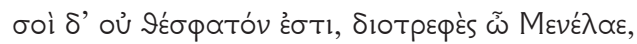

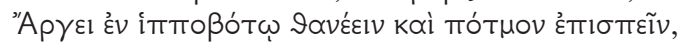

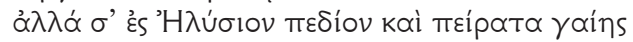

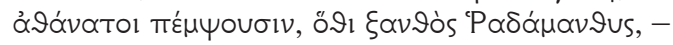

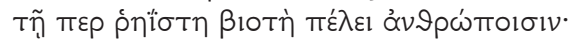

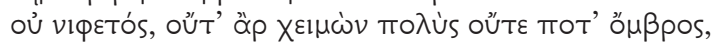

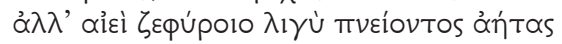

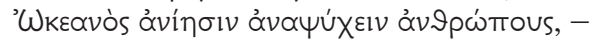

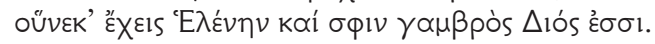

But for you it is not ordained, o Zeus-nurtured Menelaus, to die in horse-rearing Argos and meet your death, but to the Elysian plain and the ends of the earth the immortals will send you, where flaming Rhadamanthys there is life easiest for men;

it does not snow, nor is there much winter nor rain, but always the Oceanos sends up blasts of the west wind blowing loudly to refresh mortal men -

for you have Helen and you are to them the son in law of Zeus.

There is nothing in the four PLs for these two characters which can reasonably be held to allude to these later events, whether we think of Agamemnon's fears of Menelaus' death in Troy and the abuse of his brother's tomb by the Trojans as a mark of his own dishonour (Il. 4.171-

92 Cf. LFGE s.v. B. 
182), or [5] Penelope's emphasis on her grief for her lost husband (Od. 1.342-344), or [7] anything in her long and varied exchange with Odysseus in Book 19 about the woes she faces, has overcome hitherto, and which still threaten her, or [8] in her exchanges with a range of characters about the bow contest. ${ }^{93}$

One can see this again even in those cases which have left less of a mark on the records of early Greek epic, such as that of Telemachus [6], of whom we only learn in the post-Homeric ${ }^{94}$ Telegonia that he went to live with Circe on Aeaea (arg. 17-20 Bernabé). Unless one sees in Penelope's typical complaint about his unknown whereabouts (727-731) an allusion to his later 'translation' on Aeaea, there is nothing in this scene which seems to allude to this fact. There is certainly no hint here about the actual form of his death or funeral, or any such scene of lamentation for him. In this sense, the direct relationship between the PL and AL for Hector in the Iliad is actually rather atypical.

So, if an allusion to an AL is not automatically associated with scenes of PL, what relationship to the narrative future - if any - does it have? We have already observed the role of the rebuff in the PL sequence, the reaction to the lamentation in which the speaker points out that the mourner's fears or expectations are misguided. Indeed, the mourner is always wrong, not about the fact that their loved one is going to die (if we leave aside Telemachus and Menelaus), but at least about the immediate danger as the source of their fear: [1] Menelaus is at no risk of dying from this wound, nor of dying in Troy; [2] Andromache and her servant women fear that Hector will not return home again (6.501-2), yet the army does return to Troy that night $(7.310,370-371,379-$ 380); [4] Hecuba (and Priam's philoi 24.327-328) think that he will not return from the Greek camp (201-208); [5] \& [7] Penelope is convinced that Odysseus is already dead and will not return, and actually then takes steps to hasten her departure from the house which would confirm the fact [8]; [6] similarly, Penelope believes that Telemachus will not return safely from his journey to Sparta and Pylos. Of course, these errors are only natural, given the fact that the lamenting figures are all human beings, prone to such limitations of knowledge, and the

93 We might also remember that in the post-Homeric Telegonia, Odysseus' body is translated to Circe on Aeaea for burial, where Telemachus marries Circe and Penelope Telegonus, and both are made immortal (Telegonia arg. 17-20 Bernabé).

94 See above, n. 14, for the sense in which I use this term. 
menfolk in question are in danger. So the instincts of the lamenting figures are neither unreasonable nor wildly off track, for it takes some particular divine favour to protect (e.g.) Menelaus, Priam, Telemachus and Odysseus from the envisaged threat, whilst Hector will meet his death only a few days hence.

There is no single or simple way in which the error is marked or determined in each episode. In some examples, it comes in the (more) public setting, as in [1], [4], [5], [7] and [8]. But even in those cases where the error seems to come most obviously and prominently from the private PL, as in [2], [6] and [8], there is still a misapprehension on the mourner's part about the immediate dangers in the first PL: [2] Andromache gives a series of sound tactical pointers to her husband (Il.6.429-439), wrongly believing (as Penelope does in [5] when she thinks she has a role to play in determining the subject of Phemius' song before the suitors) that she could have a role in advising caution and defensiveness to a husband who has no desire to limit himself to such behaviour. She also feels, quite reasonably in the circumstance, that the city will be vulnerable to an external assault in a previously attacked spot - but the audience knows that the city will not be taken by storm, and certainly not in the immediate circumstances of this poem; [6] Penelope's conversation with Medon opens with her outraged queries about the further iniquities on which the suitors are engaged in destroying Odysseus' household (Od. 4.681-695), and her initial reaction to the news of her son's departure shows her conviction that he will die on this trip (706-710).

How then, is error about the future to be found in Thetis' scene? There is no single rule to be followed here, as we have seen, so it could be located in either the first stage of the sequence with the Nereids under the sea or during the second in the Greek camp. The first PL, however, contains no specific mention of any immediate danger, rather than focusing on the inevitability of Achilles' death in Troy (18.54-60), though we might consider that Thetis' error could lie in thinking that 'whilst he lives and looks on the light of the sun, he grieves / nor am I able to help him' (Il. 18.61-62) - for she will help him to achieve his vengeance upon Hector. But that hardly responds to the common feature of the other examples, that the error should concern the immediate danger facing the beloved.

She does express an opinion on that, however, in her famous prediction of the immediacy of Achilles' doom (18.95-96): 


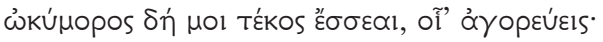

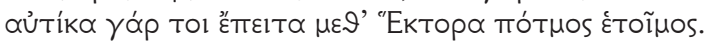

Then you will be swift to die, such are your words; for straightaway then after Hector is your doom ready.

This prediction has always seemed rather problematic, for later recorded traditions from the 'Epic Cycle' make it clear that there were quite a few episodes intervening between the deaths of Hector and Achilles - Penthesileia and Memnon being the chief ones (Aethiopis arg. 4-15 Bernabé). Some scholars think this is an example of Homer attempting to preclude known, and rival, stories; ${ }^{95}$ others have argued that it shows his ignorance of those stories; ${ }^{96}$ still others have opined that this is one of Homer's famous 'nods', ${ }^{97}$ and the Neoanalysts have predictably concluded that her prediction would much better fit the situation facing Achilles before his fight with Memnon, immediately after which Achilles perishes (Aethiopis arg. 12-16 Bernabé).${ }^{98}$ But the typical framework of the PL, in which the mourner is always mistaken about the immediate danger facing the threatened figure, provides us with a

95 Cf., e.g., Currie 2006, 31, who attempts to have it both ways: "the poet need not always have his eye on how a putative continuation of his song could be reconciled with tradition ... Iliad 18.96 'quotes' the *Memnonis (Aithiopis) while simultaneously negating its plot”; contra, e.g., Scodel 2004 passim.

96 Cf. West 2003b, 7 for discussion.

97 It is not a little ironic that Kullmann (1960, 37-39) explains Thetis' prediction by reference to the errors typical of oral poets, but this is an impossible conclusion anyway, for Lohmann 1970, 142 (above, n. 76) has shown the centrality of Thetis' speech to the structure of the entire scene: Homer wanted not only that prediction, but more precisely he wanted his audience to recognise its importance. Hence Lohmann (144-145) tolerates the "kleine sachliche Ungenauigkeit" (145) because of the advantages of the theme's development and its effect in this scene (cf. 145 and n. 81 for his condemnation of the Neoanalytical case): Achilles' desire not to live any longer (18.88-93) becomes intensified in Thetis' upping of the ante ('straightaway then' 95-96), which he takes to the next level in his reply ('straightaway may I die!' $98 \mathrm{ff}$.) before returning to the acceptance of his fate at some point in the future (115ff.); the theme thus follows the emotional development of the scene, and Lohmann's demonstration is strengthened by the realisation that PL demands an error of the sort expressed here.

98 Cf., e.g., Burgess 2009, 87: "the remark by Thetis is a transferred motif that evokes the situation before the battle between Achilles and Memnon"; contra Hölscher 1955, 394-395. It should be remembered that the order of events in Proclus' summary has the conversation between Achilles and Thetis about тờ Kaтó тóv Méuvova before the death of Antilochus (arg. 12-13 Bernabé). 
much simpler explanation for this prediction - Thetis is wrong: Achilles is not to die 'straightaway' after Hector.

This may seem, on first and perhaps second sight, an absolutely outrageous suggestion. Throughout the poem, Thetis' special knowledge about the future is frequently assumed: Achilles refers to her famous information about his twin fates $(9.410-416$; cf. 17.404-411, 21.276278; also 19.416-417, 22.359-360, 23.80-81); Nestor feels that some such information could have motivated Achilles not to fight (11.794-795); Achilles again remembers a previous prediction of hers that the best of the Myrmidons would die whilst he lived (18.8-11); and so on. Of course, she does have a more privileged access to this kind of information than other lamenting females (all of whom are mortals), ${ }^{99}$ but nowhere in the poem is it suggested that she is infallible. On a broader level, we should never expect infallibility on the part of any of the (other) gods, for only Zeus has the final say over the course of both narrative and history, and several of her pronouncements are explicitly linked with him (esp. 17.404-411, 11.794-795). Whatever their individual moments of influence or insight (as for instance Hera with Zeus over the fate of Sarpedon $(16.431-461)$ or Poseidon with Hera (20.291-319) over that of Aeneas), the other gods are generally kept in the dark about his opinions and intentions throughout the Iliad and Odyssey until the moment, as he says to Hera, when he decides to reveal 'whatever it is fitting to hear' (1.547). ${ }^{100}$ If it is possible for Hera, Poseidon and Athene not to be certain that Zeus will indeed permit the sacking of Troy, then it is surely possible that Thetis can be misinformed about the precise circumstances of her son's death.

But it might be objected that there are other mentions of Achilles' death in this poem which also make a similar connection, at least in terms of the timing of that event: ${ }^{101}$ for Xanthos it is 'near' (19.409), and for Thetis later in the poem it is 'close by' (24.132). Yet, equally, for Hera it is 'later' (20.127), whilst Hephaestus is as vague in this regard $(18.464-467)$ as is Achilles himself $(19.421-422,21.111)$ and Hector in his dying prediction $(22.358-360)$. From an immortal perspective, of course, any event in the lives of wretchedly transient mortals is near, and the famous words of Glaucus to Diomedes or Apollo to Poseidon

99 West 1966 ad Th. 233, 233 (also ad 240-264, 235) notes that marine deities are frequently linked with prophetic powers.

100 Cf. Schäfer 1990 passim; also Allan 2008, 208 with n. 18.

101 Cf. Edwards 1991 ad 18.95-96, 158, for discussion. 
ring particularly true here (Il. 6.146-149, 21.464-466), ${ }^{102}$ but there is in any case no great stretch of time - even to a mortal - between the death of Hector and the fall of Troy. Homer is creating above all a causal connection between the events, but Thetis' mistake - or exaggeration, if you prefer - leaves room for other stories to intervene between the end of his poem and the end of its hero's life. ${ }^{103}$

The poet's decision to use PL here allows us to observe him fitting his own into the existing stories of Achilles' death, and thereby to resolve the longstanding crux over Homer's apparent ignorance or dismissal of the arrivals of Penthesileia and Memnon at Troy. ${ }^{104}$ The relationship between the Homeric Iliad and the future of Achilles is an inclusive, accommodating one, but we would never be able to see this if we were blind to the ways in which the poet constructs his narrative. Just as Andromache, Agamemnon, Hecuba and Penelope are wrong in the immediate circumstances about their menfolk, so the divine Thetis - for all the superiority she possesses specifically as a lamenting figure - is mistaken about the future of her son.

\section{Conclusion}

An appreciation of Homer's typical patternings - in this case, prospective lamentation - shows more clearly the structural and semantic purpose of the mourning elements to be found at the start of Iliad 18. They are not inappropriate or unexpected there, nor do they require a reference or allusion to Achilles' actual death and funeral in order to be understood in their context, as the earlier Neoanalysts contended. None of this means that Homer is not trying also to remind his audience of that event, as some newer Neoanalysts might argue, ${ }^{105}$ but this is not the

102 Cf. Burgess 2001, 117-127, 190-191; Kelly 2007, 289-290.

103 Cf. also Scodel 2004. Burgess (2009, 15-19) makes the point that other stories about the relationship between Thetis and Achilles are presupposed on her continually trying unsuccessfully to prevent his early death, so that her error here would fit entirely with the motives traditionally associated with her character.

104 In fact, Homer does more than fit it in, because he places the erroneous prediction at the very centre of the scene's structure (cf. above, nn. 76 and 97 for Lohmann's analysis), highlighting it within the PL itself and commenting powerfully on his character's limitation.

105 We await Currie (forthcoming). In some sense, traditional Neoanalysis made for a more rigorous and satisfying method: problems in the Homeric text ne- 
only nor even the most important source of significance within this episode, so simply substituting the terms 'allusion' or 'interaction' for the older 'dependence' and 'derivation' is no real progression, and is subject to the same range of criticisms; the conventional nature of the scene shows that it cannot be assumed to be directed primarily towards the post-Iliadic story of Achilles.

The Neoanalytical emphasis on the scene at the start of Iliad 18 will prove to have been beneficial, for it has forced us to examine the structures of Homer's narrative much more closely than we would otherwise have done. Yet, even as we move forward into a new period of rapprochement, we cannot forget that this emphasis has ignored the typical patterns underlying Homeric narrative and their meaning, and deployed instead an unhelpful and misleading series of criteria in order to demonstrate Homeric dependence on other texts / poems / stories. This has been done usually without considering the very special circumstances of orally derived traditional epic, or even discussing what criteria are appropriate for poetry of this sort. Once we understand the poem's typicality, our attitude to the very notion of 'appropriateness' must change also.

However useful in other cases, the Neoanalyst's drive to see behind the poem in this way cannot be employed in this case: there is no compelling reason to conclude that Homer is drawing on anything other than traditional, typical resources in his construction of the episode, nor that he is particularly alluding to an episode from another text / poem / story instead of trying to create significance within his own narrative. When Jonathan Burgess says that "the mourning of Thetis and the Nereids belongs to one situation only, the famous funeral of Achilles ... the book 18 scene therefore seems like a significant evocation of the funeral of Achilles", ${ }^{106}$ he is unlikely to be right in those exclusivising

cessitated the invocation of sources in order to explain and solve them, so that there was a strong, in some cases inexorable, argumentative drive for every step in the method. There is no such logical necessity to its newer form, which seems often to amount to little more than saying that there might be a connection to another text / poem / story, because there are striking similarities between the Homeric text and its putative source (cf. above, n. 20). But shouldn't we expect similarities between texts originating at this period in the history of Greek literature, and without seeing those resemblances necessarily as evidence of a genetic relationship? Whilst avoiding some of the pitfalls of its earlier cousin, the newer version seems nonetheless to have fallen straight into the other traps by which Neoanalysis is dogged.

106 Burgess 2009, 83; also Edwards 1990, 312: “the tableau of Achilles' grief, with his mourning mother holding his head in her arms and the lamenting sea- 
terms, and the artistic evidence adduced earlier certainly gives us no reason to think so. ${ }^{107}$ Any allusive purpose, when viewed in the light of Homer's traditional technique, is an ancillary factor to an understanding of Thetis' prospective lamentation for her son. Once we cease seeking to explain Homer by reference to uncertainly attested texts / poems, and instead concentrate our attention on the techniques actually evidenced within the Iliad, we cease to be distracted from the primary duty of explaining the text we have on its own terms. If we are to draw on that which is useful within the rich and productive heritage of Neoanalysis, we must not be blind to that which should be questioned - and then discarded. ${ }^{108}$

\section{Appendix - PL sequences in Homeric poetry}

I. PL 1 - the first (more public) individual stage

\begin{tabular}{|r|l|l|l|}
\hline Case & Setting & Lamentation & Rebuff \\
\hline [1] & Battlefield (Il. 4.79-80) & Agamemnon (148-149) & $\begin{array}{l}\text { Menelaus } \\
(183-187)\end{array}$ \\
\hline [2] & $\begin{array}{l}\text { Scaean gates (Il. 6.392- } \\
394)\end{array}$ & Andromache (406-439) & $\begin{array}{l}\text { Hector (441- } \\
465)\end{array}$ \\
\hline$*[3]$ & Neleus' cave (Il. 18.35-36) & Thetis (18.51-64) & - \\
\hline$*[4]$ & $\begin{array}{l}\text { Priam's house (Il. 24.160- } \\
161)\end{array}$ & summary (160-168) & Iris (171-187) \\
\hline [5] & $\begin{array}{l}\text { public area of Od.'s house } \\
\text { (Od. 1.330-335) }\end{array}$ & Penelope (336-344) & $\begin{array}{l}\text { Telemachus } \\
(345-359)\end{array}$ \\
\hline
\end{tabular}

nymphs around them (II. 18.65-147), seems to invoke the scene of his funeral".

107 Cf. above, nn. $87-88$.

108 I would like to thank Antonios Rengakos and Christos Tsagalis for their invitation to the conference where the material on which this article is based was presented, and the conference participants for their stimulating questions and discussion. I would also like to thank Bill Allan, Jonathan Burgess, Bob Cowan, Bruno Currie, Sarah Harden and Oliver Thomas for reading and commenting on earlier drafts, and Monika Murdoch Asztalos, Øivind Andersen and everyone at the Institutt for filosofi, ide- og kunsthistorie og klassiske språk at the University of Oslo for inviting me to give a seminar on this material in December 2009, and for their perceptive muthoi and generous xenia afterwards. 


\begin{tabular}{|r|l|l|l|}
\hline Case & Setting & Lamentation & Rebuff \\
\hline [6] & threshold female quarters & $\begin{array}{l}\text { Penelope (680-695, } \\
703-710)\end{array}$ & $\begin{array}{l}\text { Medon }(711- \\
714)\end{array}$ \\
\hline [7] & $\begin{array}{l}\text { public area of Od.'s house } \\
\text { (Od. } 19.51-52)\end{array}$ & $\begin{array}{l}\text { Penelope (summ.) }(204- \\
213,249-351)\end{array}$ & $\begin{array}{l}\text { Odysseus } \\
(582-587)\end{array}$ \\
\hline [8] & $\begin{array}{l}\text { (a) storeroom of Od.'s } \\
\text { house }\end{array}$ & $\begin{array}{l}\text { (a) Penelope (summ.) } \\
\text { (55-56) }\end{array}$ & - \\
\hline & $\begin{array}{l}\text { (b) public area Od.'s house } \\
\text { (Od. } 21.63-66)\end{array}$ & $\begin{array}{l}\text { (b) Penelope (67-79 } \\
\text { etc.) }\end{array}$ & $\begin{array}{l}\text { Telemachus } \\
(344-353)\end{array}$ \\
\hline
\end{tabular}

II. PL 2 - the second (more private) group stage

\begin{tabular}{|c|c|c|c|}
\hline Case & Setting & Lamentation & Rebuff \\
\hline [1] & - & - & - \\
\hline [2] & Hector's house (Il. 6.497-498) & $\begin{array}{l}\text { Andromache and maids } \\
\text { (summ.) }(498-502)-\end{array}$ & \\
\hline$*[3]$ & $\begin{array}{l}\text { Myrmidon ships (Il. 18.67- } \\
69 \text { ) }\end{array}$ & Thetis $(70-77,95-96)$ & $\begin{array}{l}\text { Achilles } \\
(97-126)\end{array}$ \\
\hline \multirow[t]{3}{*}{$*[4]$} & $\begin{array}{l}\text { Priam's bedroom (Il. 24.191- } \\
\text { 192, 237-238, 281-282) }\end{array}$ & (a) Hecuba (200-216) & $\begin{array}{l}\text { Priam } \\
(217-227)\end{array}$ \\
\hline & & (b) Trojans (237) & $\begin{array}{l}\text { Priam } \\
(239-246)\end{array}$ \\
\hline & & (c) sons $(249-251)$ & $\begin{array}{l}\text { Priam } \\
(252-264)\end{array}$ \\
\hline [5] & $\begin{array}{l}\text { female quarters }(O d .1 .360- \\
362)\end{array}$ & $\begin{array}{l}\text { Penelope and maids } \\
\text { (summ.) (362-363) }\end{array}$ & - \\
\hline [6] & $\begin{array}{l}\text { (threshold) female quarters } \\
(\mathrm{Od} .4 .716-719)\end{array}$ & Penelope $(721-741)$ & $\begin{array}{l}\text { Eurycleia } \\
(742-758)\end{array}$ \\
\hline [7] & $\begin{array}{l}\text { female quarters (Od. } 19.600- \\
602)\end{array}$ & $\begin{array}{l}\text { Penelope and maids } \\
\text { (summ.) (602-603) }\end{array}$ & - \\
\hline [8] & $\begin{array}{l}\text { female quarters (Od. } 21.354- \\
356)\end{array}$ & $\begin{array}{l}\text { Penelope and maids } \\
\text { (summ.) (356-357) }\end{array}$ & - \\
\hline
\end{tabular}

$*$ = reversal of sequence (viz. private group stage followed by public individual stage) 
Bereitgestellt von | De Gruyter / TCS Angemeldet | 212.87.45.97

Heruntergeladen am | 08.01.13 07:50 